\title{
Extensional Carboniferous magmatism at the western margin of Gondwana: Las Lozas valley, Catamarca, Argentina
}

\author{
*Beatriz Coira ${ }^{1,2}$, Clara E. Cisterna ${ }^{3,4}$, Horstpeter H. Ulbrich ${ }^{5}$, Umberto G. Cordani ${ }^{5}$ \\ I CIT Jujuy-Centro de Investigaciones y Transferencia de Jujuy-CONICET-UNJu, Av. Bolivia 1239, 4600, S.S.de Jujuy, Argentina. \\ 2 Instituto de Geología y Minería, Universidad Nacional de Jujuy, Av. Bolivia 1616, 4600, S.S.de Jujuy, Argentina. \\ bcoira2015@gmail.com \\ 3 Consejo Nacional de Investigaciones Científicas y Técnicas, Av. Rivadavia 1917, C1033AAJ CABA, República Argentina. \\ ${ }^{4}$ Facultad de Ciencias Naturales, Universidad Nacional de Tucumán, Miguel Lillo 205, 4000 Tucumán, Argentina. \\ claracisterna@csnat.unt.edu.ar \\ 5 Instituto de Geociências, Universidade de São Paulo, rua do Lago 562, Cidade Universitária, São Paulo, CEP 05508-080, SP, Brasil. \\ hulbrich@usp.br; ucordani2@usp.br \\ *Corresponding author: bcoira2015@gmail.com
}

\begin{abstract}
The Las Lozas volcanic sequence, which crops out at northwestern border of the Famatina belt-southeastern Puna, NW Argentina, is constituted mainly by rhyolites and a lesser volume of basalts and trachytes, and volcanoclastic deposits. These rocks, previously considered of Early Paleozoic age, are now assigned to the Lower Pennsylvanian (320 Ma U-Pb age). They represent a bimodal volcanic succession that plot in the subalkaline/tholeiitic (rhyolites), alkaline basalts (basalts) and alkaline (trachytes) fields on the total alkali-silica diagram. The basalts display features comparable to transitional MORB and within-plate tholeiites, with contributions from a mantle source affected by crustal contamination. The acid members also show geochemical affinities to within-plate magmas, and their composition suggest a derivation from continental crustal material with mantle source interaction or a juvenile essentially mantle derived crust. The $320 \mathrm{Ma}$ age from the Las Lozas volcanic succession as well as the 342 and $348 \mathrm{Ma} \mathrm{U}-\mathrm{Pb}$ ages, from rocks in the nearby Cazadero Grande section, to the south, and the U-Pb ages from Sierra Pampeanas granites (332-357 Ma) highlight the importance achieved by Carboniferous magmatic activity in that region, framed between 320 and 350 Ma. Low strontium initial ratios from the Las Lozas $(0.70479-0.70164)$ indicate a predominant contribution by a juvenile component, while the ratios in the nearby Cazadero Grande (0.71433-0.71233) and Sierras Pampeanas granites $(0.717$ to 0.7124$)$ point to an input by enriched sources with restricted contribution of a mantle component. Nd isotopes from a basalt from the Las Lozas section $\left(\varepsilon_{\mathrm{Nd}(320)}\right.$ with $+3.11, \mathrm{~T}_{\mathrm{DM}}$ with $\left.774.6 \mathrm{Ma}\right)$ indicates a possible asthenospheric source, with evidence for some mixture between juvenile and reworked crustal material. In contrast Sr-Nd isotopes in a rhyolite from Cazadero Grande $\left(\varepsilon \mathrm{Nd}_{(t)}\right.$ of -2.91 and $-0.3, \mathrm{~T}_{\mathrm{DM}}$ of 1.09 and $\left.1.1 \mathrm{Ga}\right)$ and of Sierra Pampeanas granites $\left(\varepsilon \mathrm{Nd}_{(t)}\right.$ of $-0.6, \mathrm{~T}_{\mathrm{DM}}$ of 1.19 and $1.1 \mathrm{Ga}$ ) suggest a crustal source with minor juvenile input. Taking in account the age difference in the region between Mississippian and the Lower Pennsylvanian magmatism, this would indicate a change in the magma source consistent with a more pronounced extensional tectonic regime for the Lower Pennsylvanian. This assumption need to be considered together with observations along a transect at $27^{\circ} 30^{\prime} \mathrm{S}$, where the Carboniferous Eastern Sierras Pampeanas granitic rocks show, regardless of age, a greater contribution of juvenile material of mantle character to the west. Among these rocks, with a major juvenile component, are those of the Las Lozas succession as well the Cerro Gloria Granite, the eastern manifestations of the Carboniferous Eastern Sierras Pampeanas magmatism. From the foregoing emerges that the contribution of juvenile material could be continuously varied in the region through the Carboniferous, due to varying lithospheric extension. An example of this arise from the presented data of the Lozas succession, which indicate that this rocks resulted from reworking of supra-crustal material with input of juvenile magmas, linked to the change in the lithospheric extension.
\end{abstract}


RESUMEN. Magmatismo carbonífero en régimen extensional en el margen occidental de Gondwana, valle de Las Lozas, Catamarca, Argentina. La sucesión volcánica que aflora en Las Lozas, noroeste del Sistema de Famatinasureste de la Puna (noroeste Argentina), está constituida principalmente por riolitas y en menor volumen por basaltos, traquitas y depósitos volcanoclásticos. Estas rocas, previamente consideradas de edad paleozoica inferior, son asignadas actualmente al Pensilvaniano Inferior (edad U-Pb $320 \mathrm{Ma}$ ). Representan una sucesión volcánica bimodal encuadrada en los campos subalcalino/toleítico (riolitas) y alcalino (basaltos y traquitas) sobre la base álcalis-sílice. Los términos básicos muestran características comparables y transicionales a MORB-toleitas de intraplaca, con una fuerte contribución mantélica y contaminación cortical. Los miembros ácidos también muestran afinidades con magmas de intraplaca, sugiriendo su derivación de la interacción de material cortical con una fuente mantélica o de una corteza juvenil esencialmente derivada del manto. La edad U-Pb de 320 Ma obtenida para la sección de Las Lozas, al igual que las edades de U-Pb 342 y 348 Ma reportadas para rocas aflorantes en la zona de Cazadero Grande, hacia el sur; junto con las edades U-Pb reportadas para granitos de las Sierra Pampeanas (332-357 Ma) confirman la importancia alcanzada por la actividad magmática carbonífera, encuadrada entre 320 y $350 \mathrm{Ma}$, en dicha región. Las bajas razones iniciales de estroncio en las rocas volcánicas de Las Lozas (0,70479-0,70164) indican contribución de un componente juvenil, mientras que las mismas relaciones observadas en las riolitas de Cazadero Grande (0,71433-0,71233) y en los intrusivos graníticos de Sierras Pampeanas (0,717-0,7124), apuntan a magmas con participación de componentes corticales. Los valores isotópicos de $\mathrm{Nd}$ sobre un basalto en Las Lozas $\left(\varepsilon_{\mathrm{Nd}(320)}\right.$ con 3,11, $\mathrm{T}_{\mathrm{DM}}$ con 774,6 Ma) permiten argumentar una fuente astenosférica, con evidencia de mezcla entre elementos juveniles y corticales. Los isótopos Sr-Nd determinados, en cambio, para una riolita que aflora en Cazadero Grande $\left(\varepsilon_{\mathrm{Nd}(\mathrm{t})}: 2,91 \mathrm{y}-0,3, \mathrm{~T}_{\mathrm{DM}}: 1,09 \mathrm{y} 1,1 \mathrm{Ga}\right)$ y en granitos de las Sierras Pampeanas $\left(\varepsilon \mathrm{Nd}_{(\mathrm{t})}:-0,6, \mathrm{~T}_{\mathrm{DM}}: 1,19\right.$ y $\left.1,1 \mathrm{Ga}\right)$ sugieren participación cortical. Dada la diferencia de edades en la región entre el magmatismo misisipiano y pensilvaniano inferior, dichas variaciones indicarían un cambio en la fuente magmática, consistente de un régimen tectónico extensional más pronunciado durante el Pensilvaniano Inferior. Esta presunción debe ser considerada teniendo en cuenta las observaciones a lo largo de una transecta a los $27^{\circ} 30^{\prime} \mathrm{S}$, donde las rocas graníticas carboníferas de las Sierras Pampeanas Orientales muestran, sin importar la edad, un mayor aporte hacia el oeste de material juvenil de carácter mantélico. Entre estas rocas, con una mayor componente juvenil, se encuentran: la sucesión de Las Lozas y el Granito Cerro Gloria, manifestaciones occidentales de dicho magmatismo. De lo anterior se desprende que la contribución de material juvenil podría variar continuamente durante ese tiempo como respuesta a una extensión litosférica variable. Un ejemplo de esto surge de los datos de la sucesión de Las Lozas presentados, los que indican a la misma como resultado del retrabajo de material supracortical, con el aporte de magmas juveniles asociados a cambios extensionales de la litósfera.

Palabras clave: Volcanismo carbonifero posorogénico, Geoquímica, Isótopos $\mathrm{Sr}$ - $\mathrm{Nd}$, $\mathrm{NW}$ de Argentina.

\section{Introduction}

The present study deals with the volcanicvolcanoclastic section that outcrops along the Las Lozas Valley at the northwestern of the Famatina System-southern Puna (Fig. 1), to the north of the Mississippian rhyolites reported in Cazadero Grande by Martina et al. (2011) and to the west of the coeval granites of the Sierras Pampeanas (Dahlquist et al., 2006, 2013; Grosse et al., 2009). The Las Lozas rocks, previously mapped as Ordovician and considered to be part of the Famatinian magmatic system (Turner, 1967; Mpodozis et al., 1997; Rubiolo et al., 2001; Coira et al., 2005), were recently assigned by Cisterna et al. (2013) and Zappettini et al. (2015) to the Lower Pennsylvanian based on a zircon U-Pb SHRIMP age ( $320 \pm 2 \mathrm{Ma})$. Both, lower Pennsylvanian and Mississippian successions are new records of the Carboniferous magmatism in the region, locate west of the small and scattered A-type granites distributed along more than $1,000 \mathrm{~km}$ in the Sierras Pampeanas (Dahlquist et al., 2010). The geodynamic setting of the Carboniferous magmatism in the region remains controversial. It has been considered product of crustal reheating during final phase of Famatinian orogeny (e.g., Grissom et al., 1998; Llambias et al., 1998; Höckenreiner et al., 2003; Grosse et al., 2009) or part of the Achalian orogen (e.g., Sims et al.,1998; Siesgesmund et al., 2004; Dahlquist et al., 2006, López de Lucchi et al., 2004). Meanwhile Dahlquist et al., 2010 proposed that those Carboniferous granites represent a new tectonothermal event, considering their field and geochemical characteristics, indicative of an extensional within-plate setting and noncompressive tectonic regime and not syn-kinematic emplacement as has been invoked for Devonian granite of Sierras de Cordoba or San Luis (Sims et al.,1998; Siesgesmund et al., 2004).

In this paper we present, a detailed petrographic, structural, geochemical and complementary isotopic 


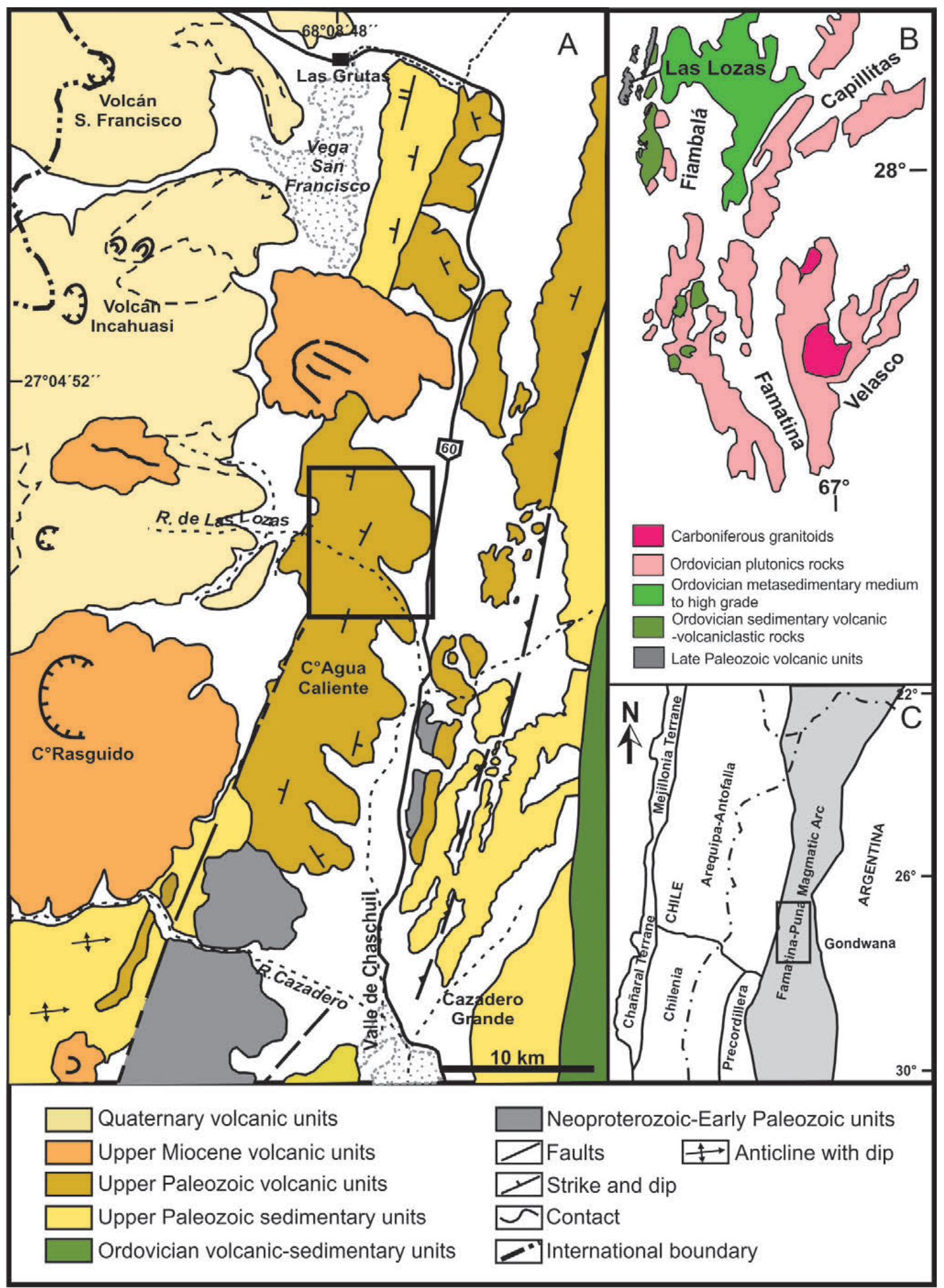

FIG. 1. A. Geological map of Las Lozas Valley showing the location of the studied area; B. Regional geological map comprising the studied area and the Sierras Pampeanas region; C. Geological setting of the Puna-Famatina-Sierras Pampeanas System, NW Argentina. 
data of the Las Lozas rocks to place constraints on their possible sources and geotectonic setting and to analyze them in relation to A-type granites from Sierras Pampeanas and to Mississsippian Cazadero Grande rhyolites, to thereby evaluate the compositional variations in time and space through the region and so contribute to improve geodynamic models in the Proto-andean margin of Gondwana during Late Paleozoic.

\section{Geologic setting}

Late Paleozoic formations overlie uncomformably a deformed Precambrian to Early Paleozoic metamorphic basement, as well as Early Ordovician granitoids (e.g., the Las Angosturas granodiorite) and Ordovician volcanic deposits (e.g., the Suri and Las Planchadas formations) at the northwestern border of the Famatina belt in the southern Puna (NW Argentina).

The formations usually identified in this region as Late Paleozoic deposits are composed mainly by extensive siliciclastic beds (the Agua Colorada and Patquia formations, members of the Paganzo Group), assigned to the Carboniferous and Permian (Turner, 1960; Cuerda, 1965). Nevertheless a Carboniferous volcanic succession has been recently identified to the west of Chaschuil valley (Fig. 1), in Cazadero Grande, where Martina et al. (2011) reported $\mathrm{U}-\mathrm{Pb}$ SHRIMP ages of $348 \pm 3$ and $342 \pm 1 \mathrm{Ma}$ and Cisterna et al. (2013) and Zappettini et al. (2015) a U-Pb SHRIMP age of about $320 \pm 2 \mathrm{Ma}$, obtained in a sample from the nearby the Las Lozas section (Fig 1). Those Carboniferous volcanic successions outcrop underlying Permian sedimentary rocks of the Paganzo Group (Seggiaro et al., 2000).

\section{Las Lozas section}

The present paper focuses mainly on the volcanic deposits exposed along the Las Lozas Valley at the southwestern limit of Catamarca province $\left(27^{\circ} 10^{\prime} 38.1^{\prime \prime}-27^{\circ} 10^{\prime} 115.9^{\prime \prime}\right.$ and 68 $07^{\circ} 16.3^{\prime \prime}$ 68 07'11.9"; Fig. 1). The outcrops are well-preserved, allowing the detailed mapping and identification of many different volcanic rocks, lying discordantly above a metamorphic basement and covered by Late Paleozoic siliciclastic continental sequences. Our studies were centered on a profile with a thickness of about $550 \mathrm{~m}$, running east to west, considered to be free of structurally induced repetitions and characterized by the abundance of rhyolite lavas and their fragmented equivalents, together with minor intercalated occurrences of basalts-trachybasalts and also trachytes-dacites (Fig. 2).

Las Lozas section rocks are deformed, displaying rock cleavage result of ductile shear processes (Cisterna et al., 2006) and on top, were gently folded and faulted during the Cenozoic (Andean) deformation. The majority of these outcrops, however, display preserved primary depositional structures (e.g., spherulites, flow bands, banding) and textures some units still retain near-glassy (cryptocrystalline) domains and mafic and felsic minerals, including phenocrysts, that appear as preserved pseudomorphs variably altered to chlorite and sericite.

\subsection{Lithofacies}

The studied profile is characterized by an abundance of rhyolite lavas and their fragmented equivalents, together with minor intercalated occurrences of basalts-trachybasalts and also trachytes-dacites. The rocks are affected by low metamorphic grade with structures indicating localized ductile deformation (Cisterna et al., 2006).

\subsubsection{Effusive lithofacies}

3.1.1.1. Rhyolites. This facies is present along the entire profile as flows reaching a thickness of about $25 \mathrm{~m}$, bordered by brecciated monomicitic equivalents both at the top and bottom of the lavas flows. Color is brown to reddish or grey to dark grey. Predominant texture is porphyritic, with plagioclase, $\mathrm{K}$-feldspar and quartz euhedral megacrysts set in a glassy, partially spherulitic microcrystalline groundmass showing well-developed flow banding. Plagioclase megacrysts, 2-5 mm in length, are blocky to lath-like, variably altered to sericite. K-feldspar may reach up to $2 \mathrm{~cm}$ in some rocks, showing alignment parallel to the flow direction. Quartz megacrysts ( 0.5 to $5 \mathrm{~mm}$ ) are euhedral to rounded, commonly presenting resorption textures. Mafic minerals, mostly oxidized biotite as small and irregular lamellae, are scarce $(<1 \%)$. Some rhyolites also present fine prismatic disoriented grains of arfvedsonite.

The groundmass consists of a finely microcrystalline quartz-feldspar mosaic, with abundant randomly oriented feldspar laths (Fig. 3a). It shows a primary banding with devitrification textures, 


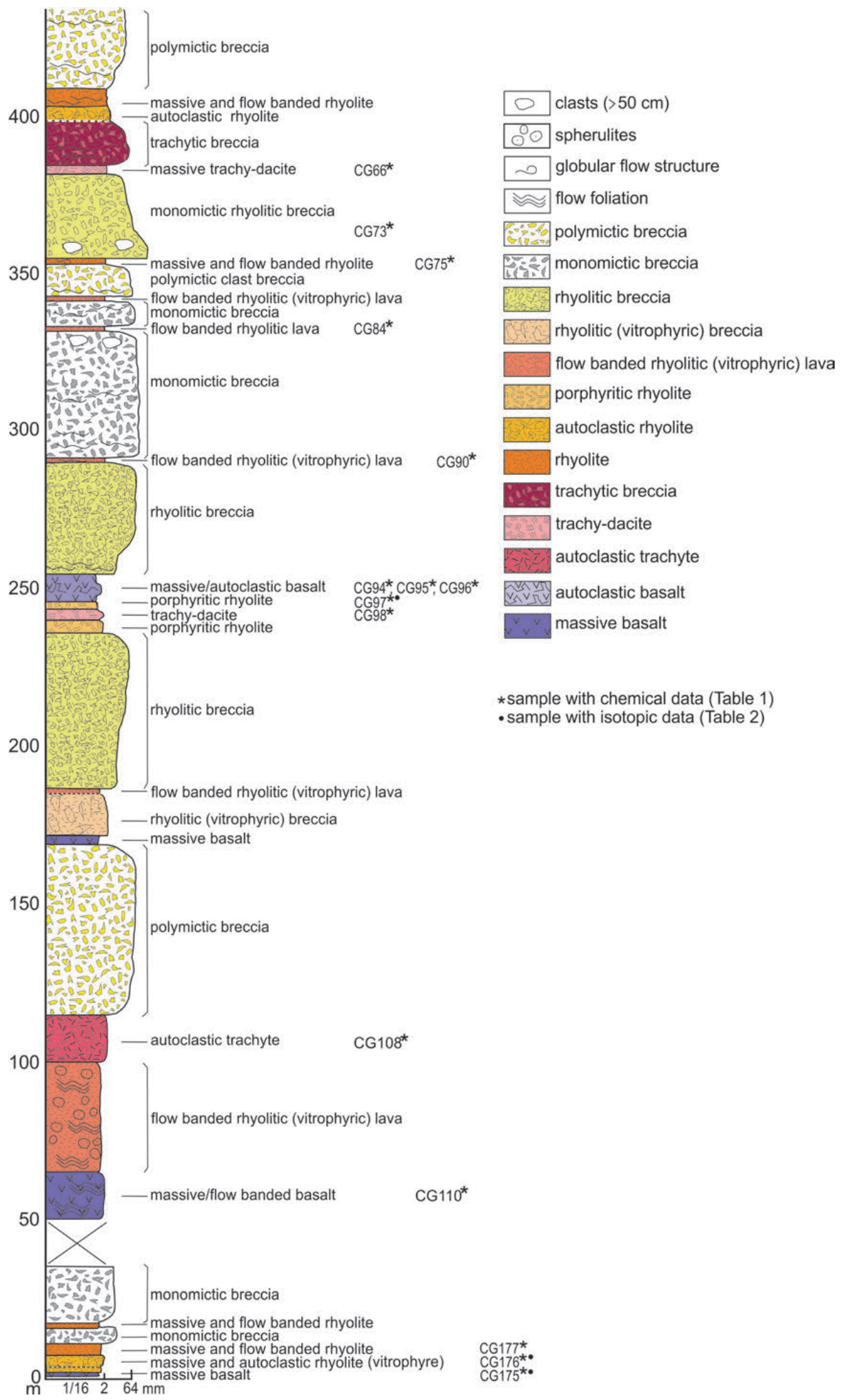

FIG. 2. Schematic log showing the internal organization of the Las Lozas section and location of studied samples. 

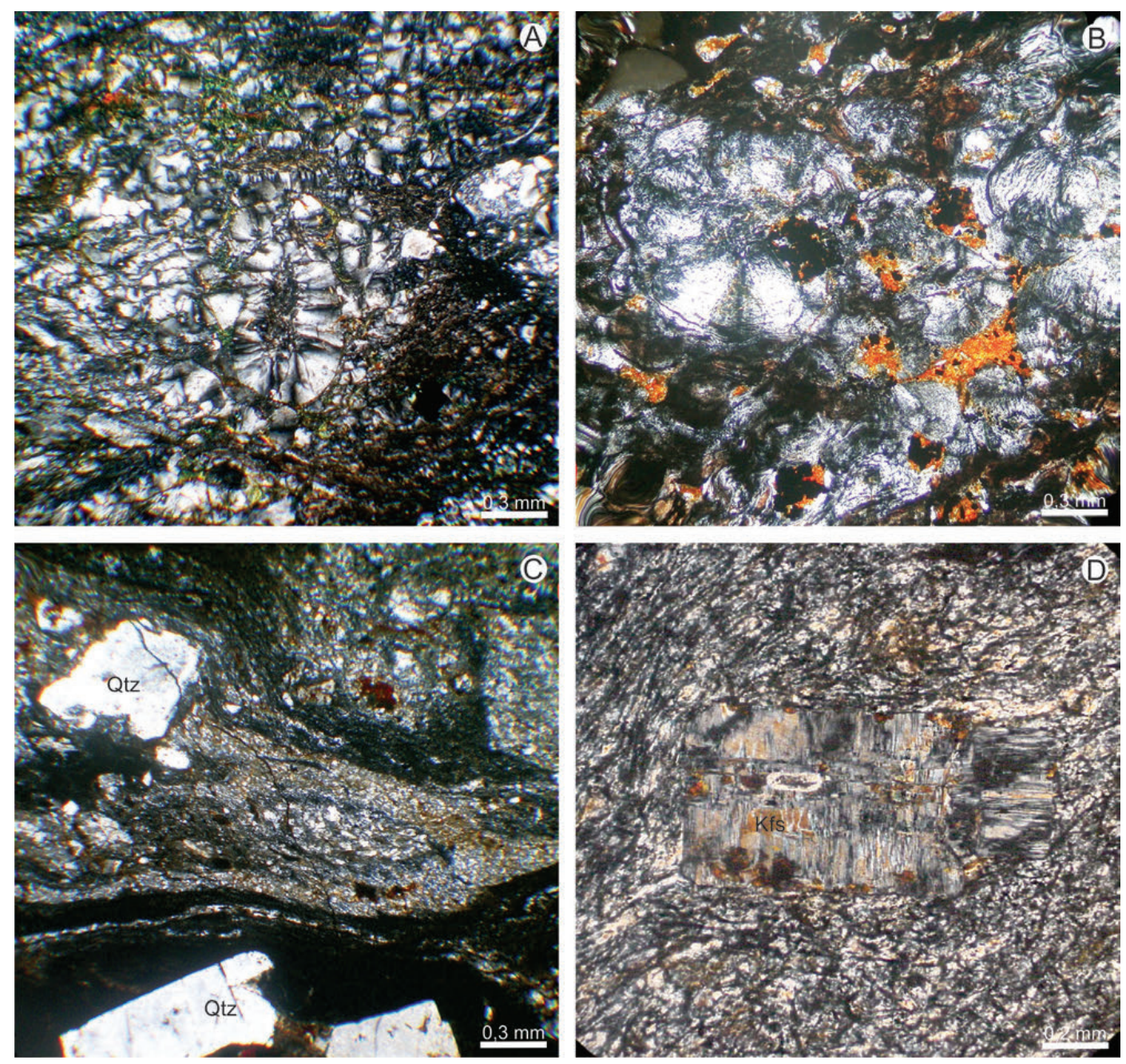

FIG. 3. Microphotograph of rhyolites showing: A. spherulitic groundmass; B. displaying cryptocrystalline to glassy groundmass with flow banding; C. groundmass of a finely microcrystalline quartz-feldspar mosaic; D. phenocryst with chessboard texture, according tofoliation. Cross polarized light.

and spherulites with microcrystalline quartz and K-feldspar as micrographic intergrowths (Fig. 3b). The rhyolites presenting predominantly spherulitic texture (with or without micrographic intergrowth) probably crystallized at higher temperatures than the rocks displaying cryptocrystalline groundmass, with a smaller degree of undercooling (cf. Allen et al., 2008). The last texture probably results from a devitrification process of a rapidly cooled glassy precursor (Lofgren, 1971; Murphy and Marsh, 1993). On the other hand, the formation of spherulitic to granophyric textures is consistent with a process of slower cooling (Lofgren, 1971).
Rhyolitic vitrophyres exhibit a cryptocrystalline or glassy groundmass with flow banding (Fig. 3c); in some cases showing vitrophyric layers alternating with others presenting devitrification features (fine granophyre together with spherulites).

Clear indications of deformation are distributed irregularly in several rhyolitic flows, attesting to the activity of localized ductile shear, also probably linked to different hydration conditions of the lavas. Some of the deformed rhyolitic layers present an altered groundmass with finely crystalline quartz, white mica, chlorite, opaque minerals and minor epidote, zircon and titanite, or show stretching of phenocrysts 
along the direction of an incipient foliation (Fig. 3d). Autoclastic structures can be observed along the profile, coherent lavas grading transitionally into fractured autoclastic beds, always poorly sorted, with a thickness of up to $15 \mathrm{~m}$, with predominance of angular to subangular rhyolitic clasts immersed in a finer-grained groundmass of fragments (Fig. 2). The blocky clasts, about $3 \mathrm{~cm}$ or more in size, show an arrangement with a jigsaw texture, presenting curviplanar fractures and non-quenched margins.

The features displayed by the rhyolite lavas and autobrecciated equivalents are consistent with an eruption mechanism through volcanic domes presenting coherent lava cores and brecciated margins (e.g., Allen et al., 2008). The groundmass of the breccias, displaying a banded structure, with fragments showing spherulitic and granophyric intergrowths but also glassy and perlitic textures, suggest a high temperature environment active during their emplacement.

3.1.1.2. Trachytes to trachydacites. These rocks outcrop at the upper levels of the Las Lozas section (Fig. 2), presenting dark-colored beds up to $15 \mathrm{~m}$ thick. These units are lava flow mainly autobrecciated with angular clasts ranging from 3 to $10 \mathrm{~cm}$ in size. Their texture is porphyritic, with predominant $\mathrm{K}$-feldspar phenocryts (10-15\%) up to $3 \mathrm{~mm}$ in size, and irregular vesicles (1 to $2 \mathrm{~mm}$ ). K-feldspar show chessboard texture. Mafic minerals are subordinate (subhedral augite and hornblende). The groundmass is greenishbrown, with a trachytic, partly glassy, texture with weakly to moderately oriented feldspar microlaths. Vesicles, filled with iron oxides and quartz, may be aligned parallel to the flow direction. The preexisting glass is converted into quartz-feldspar aggregates and/ or altered into chlorite. Inclusions of subrounded to irregular lithic fragments of volcanic rocks with a very fine-grained groundmass, partly flow-banded, are also observed under the microscope.

\subsubsection{Basalts. These rocks occur at the basal and} the middle of the Las Lozas section as concordant tabular bodies, with a thickness varying between 2 and $15 \mathrm{~m}$ (Fig. 2). The rocks are greenish to dark grey, generally massive and porphyritic, but also fine-grained. Locally, basalts present flow banding, partly enhanced by the flow orientation of irregular vesicles $(2 \mathrm{~mm}$ to $1 \mathrm{~cm})$, and filled with chlorites and iron oxides.
The porphyritic basalts show phenocrysts (5-10\%) including predominant, partly fractured, plagioclase (1-2 mm; Fig. 4a) and lesser amounts of augite $(1 \mathrm{~mm})$. Variolitic textures can be observed in some instances. Titan-augite, as main mafic mineral, is commonly fractured and partly altered, along fractures, to chlorite and opaque phases. The groundmass is green to brownish and the texture is usually ophitic to subophitic (Fig. 4b). Plagioclase microlites, augite grains, apatite and abundant opaque phases are also present in the groundmass, in part altered to chlorite. Glass in the groundmass is altered to palagonite. Vesicles are zoned and filled with chlorite and albite.

The basalts outcropping in the middle of the section are concordant lava flows, generally displaying autoclastic facies (Fig. 2) at their margins. Clasts, sometimes with altered margins, are angular, ranging among 3 to $5 \mathrm{~cm}$, rarely reaching up to $60 \mathrm{~cm}$. The autoclastic facies can be formed as a response to locally high strain rates in an already more brittle lava body, creating fragments, especially at the outer border of the flows, continually being dislodged by the lava movement (e.g., McPhie et al., 1993).

\subsubsection{Volcanoclastic lithofacies}

These deposits, occur as extensive tabular bodies, represent the thickest members in the Las Lozas succession and are almost entirely composed of lavas clasts. We recognized both monomictic and polymicticbreccias (Fig. 2).

\subsubsection{Monomicticrhyolitic breccia lithofacies. This} monomictic facies, present in the entire sequence, is composed by lava clasts and forms tabular bodies with sharp boundaries, up to $50 \mathrm{~m}$ in thickness. It consists of poorly sorted rhyolitic angular-subangular clasts. The breccias are dominantly grayish-brown to dark grey, massive, locally with a foliated structure due to alignment of clasts by flow. Sizes of clasts vary among 1 to $5 \mathrm{~cm}$, rarely reaching up to $60 \mathrm{~cm}$ : clast proportions may vary between 10 to $45 \%$ of the total. Clasts are rhyolitic lava fragments showing textural variations as described for the rhyolites (cf. above; such as: rhyolitic porphyritic fragments; fragments composed by a fine microcrystalline quartzfeldspar mosaic (Fig. 4c); clasts with granophyric or spherulitic textures; sometimes, clasts with flow orientation. Groundmass is microcrystalline, with flow structure, sometimes winding around crystals or lithic fragments, with appearance of pressure 

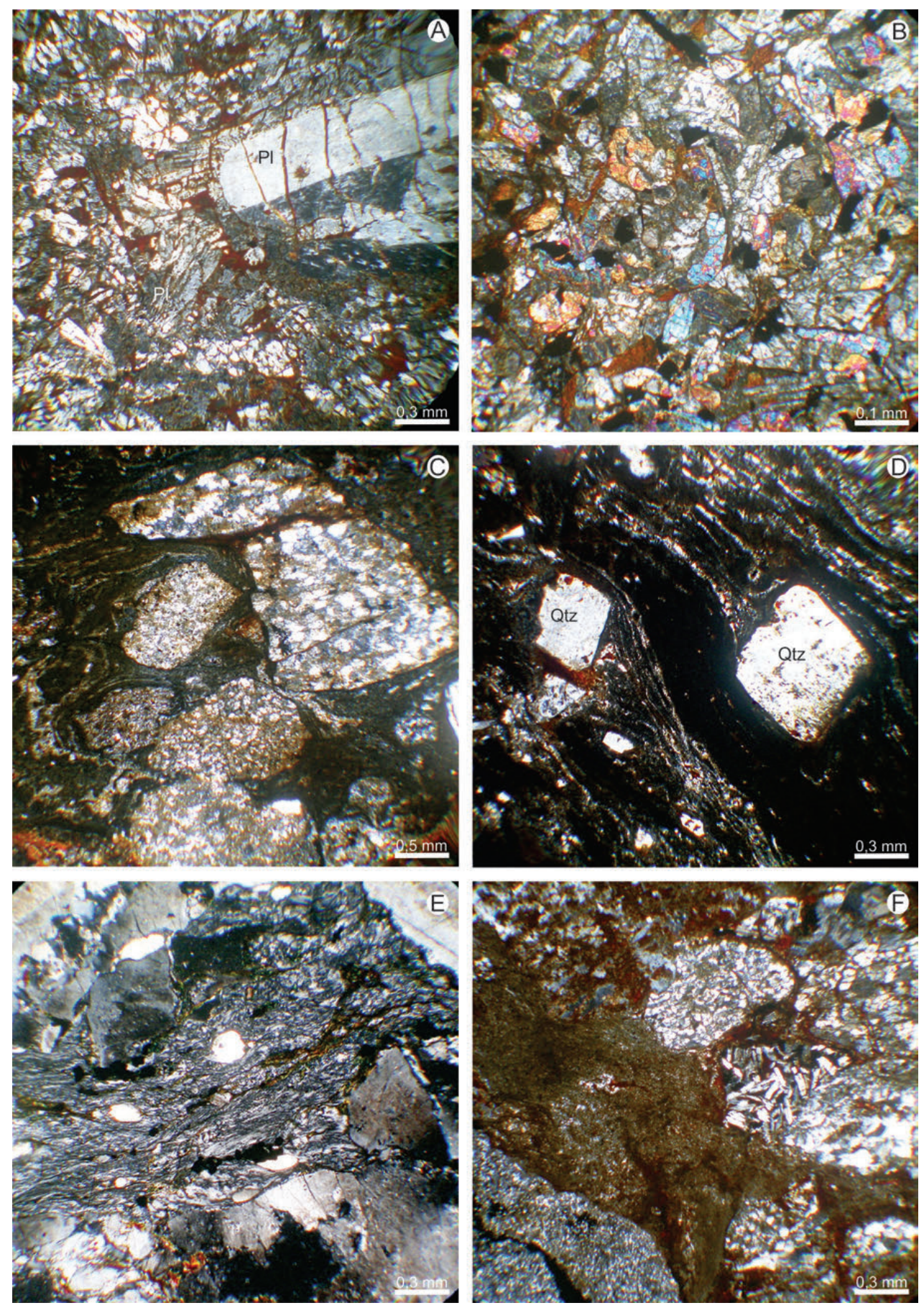

FIG. 4. Microphotograph showing: A. porphyritic basalt with plagioclase phenocrysts and lesser amounts of augite immersed in a groundmass of plagioclase microlites, augite grains, apatite and abundant opaque, in part altered to chlorite; B. basalt with ophitic to subophitic texture; C. Monomictic rhyolitic breccias with rhyolitic lava fragments showing textural variations like porphyritic or fine microcrystalline quartz-feldspar mosaic; D. groundmass of monolithic breccia, with flow structures contorting around lithic fragments and crystals with common development of foliation consisting of alternating glassy and devitrified bands; E. polimictic breccia with clasts of rhyolitic lavas and minor basalt clasts; F. banded structure in polimictic breccias with flow orientation around lithic fragments. Cross polarized light. 
shadows and a foliation consisting of alternating glassy and devitrified bands (Fig. 4D). Irregular vesicles are filled with iron ore, quartz, and other secondary minerals. Upper portions of the profile may show breccias with finer clasts.

\subsubsection{Rhyolitic vitrophyric breccia lithofacies.}

This facies is represented by a single tabular body $13 \mathrm{~m}$ thick appearing in the upper section of the studied profile (Fig. 2), with a basal transitional contact with the underlying rhyolite and a sharp upper contact. Color is dark grey, showing a foliated structure resulting from compositional banding in the groundmass and the aligned disposition of flat rhyolitic clasts. Clasts constitute about 70 to $80 \%$ of the rock; they range in size between 1 to $3 \mathrm{~cm}$, are angular, and mostly flat. Some portions of the breccias are disposed in a jigsaw arrangement, while other are only partially fractured. Under the microscope, the groundmass is frequently flow-banded, with alternating fine-grained quartz-feldspar mosaics and spherulitic bands, in part also perlithic.

\subsubsection{Polymictic vitrophyric breccia lithofacies.}

These rocks constitute the most extensive breccia deposits, crop up as tabular bodies up to $60 \mathrm{~m}$ in thickness (Fig. 2), with the basal and upper contacts relatively sharp. They are predominantly brown or dark grey and massive, but show locally a floworiented structure, evident through aligned clasts and internal flow banding (Fig. 4E). The breccias are very poorly sorted, with clast proportions reaching between 20 to $50 \%$ of the rock. Clasts are 1 to $5 \mathrm{~cm}$ in size and may reach up to $60 \mathrm{~cm}$. The beds may show an increase in the clast size in the upper parts of the tabular bodies. Lithic angular to subangular components are usually predominant, composed mainly by rhyolitic lava fragments with minor proportions of basalt clasts (Fig. 4F). Clast proportion in these beds usually increases towards the top. Thin sections show the banded structure with flow orientation (glass or oxidized fragments flowing around lithic fragments), sometimes presenting a foliation constituted by recrystalized quartz and feldspar aggregates, with granophyric textures or with spherulites. Crystal fragments (5 to 10\%) are formed by subhedral fractured feldspars and quartz, up to $3 \mathrm{~mm}$ in size. Lithophysae $(<1 \%)$ are also observed, composed of concentric shells of finely crystalline quartz and feldspars. Irregular vesicles, filled with quartz and iron minerals, are also present in the breccias fragments.

\section{Geochemistry and Isotopic Data}

The geochemical and isotopic analysis of the volcanic rocks of Las Lozas valley presented here were aimed to define the source of their magmas and to compare with Cazadero Grande rhyolites and coeval granites of Sierras Pampeanas data. As well as to provide new elements to differentiate them from the Ordovician volcanic sequences lacking stratigraphic control, outcropping at the northern portion of the Famatina System and southern Puna.

\subsection{Methodology}

\subsubsection{Rock geochemistry of major, minor and trace elements}

Analytical determinations of major, minor and trace elements from Las Lozas valley profile were performed at the XRF and chemistry-ICP laboratories of the Instituto de Geociências, University of São Paulo, Brazil.

The XRF data were obtained from prepared pressed pellets and fused glass discs. Pressed pellets were prepared from rock powders (ground to less than 200 mesh), micronized to less than 5 microns in a vibratory rod mill with ethanol, and dried overnight at $60{ }^{\circ} \mathrm{C}$. An amount of 7,000 grams of the micronized powder was homogenized with 1,400 gram wax, and pressed for 60 seconds at $30 \mathrm{KPa}$. The fused glass discs were obtained from $1,000 \mathrm{~g}$ of the powder sample, weighted with a Claisse commercial flux (mixture of $67 \%$ lithium tetraborate and 33\% lithium metaborate), positioned in a Pt crucible in a Claisse automatic melting machine and fused at $1,000{ }^{\circ} \mathrm{C}$, then poured into Ptmoulds. Analytical determinations for these elements were performed in Siemens XR fluorescent equipment, using a set of 40 international rock standards to generate a reference line (for more information, see Mori et al., 1999).

PerkinElmer ICP equipment was used to analyze the same rock powders for the determination of most trace elements. Preparation of the solutions from powders (ground to less than 200 mesh) uses an amount of $0.04000 \mathrm{~g}$ of powder, dissolved with an acid mixture of $\mathrm{HF} / \mathrm{HNO}_{3}$ in a Parr bomb at $200{ }^{\circ} \mathrm{C}$ for 5 days. After this, $\mathrm{HF}$ is eliminated as $\mathrm{SiF}_{4}$ on a hot plate and the solution diluted in the ratio 1:2000 
in $0.1 \mathrm{~N} \mathrm{HNO}_{3}$. The reference curve was obtained preparing standard materials in the same way, for which the following reference samples were used: granites GA, GH, OU-3, and YG-1 and the basalt BE-N, besides a blank (for details, see Navarro et al., 2008).

\subsubsection{Strontium and neodymium isotopes}

$\mathrm{Rb}-\mathrm{Sr}$ analyses were madeon CG-14 (vitrophyre), 97 (rhyolite) and 176 (vitrophyre) samples at the Geochronological Research Center, University of São Paulo, Brazil (CPGeo-USP). Those analyses were made by isotope dilution following the procedures indicated in Tassinari et al. (1996), employing a Micromass VG-sector mass spectrometer. For the basalt CF-175, the ${ }^{87} \mathrm{Sr} /{ }^{86} \mathrm{Sr}$ isotopic ratio was measured in the same instrument, but the indicated total $\mathrm{Rb}$ and total $\mathrm{Sr}$ values were obtained by XRF. For a similar range of values, the normal precision in the $\mathrm{Rb} / \mathrm{Sr}$ ratio at the CPGeo is always better than $2 \%$. Basalt sample CG-175 was also analyzed for Sm-Nd isotopes at the CPGeo-USP, using a Finnigan-MAT multi-collector mass spectrometer, with analytical precision better than $0.002 \%(2 \sigma)$. The methodology is described in Sato et al. (1995).

\subsection{Results}

\subsubsection{Major and trace elements}

The majority of the analyzed rocks can be divided into basic ( 41.83 to $49.97 \% \mathrm{SiO}_{2}$ ) or high silica ( 77.13 to $69.00 \%$ ) groups cf. Table 1 , although rocks with some intermediate compositions are also present (Table 1). On the total alkali $\left(\mathrm{Na}_{2} \mathrm{O}+\mathrm{K}_{2} \mathrm{O}\right)$-silica diagram (Le Bas et al., 1986), the felsic members fall into the rhyolite field and the subalkaline-tholeiitic series, the basic rocks plot within the alkaline basalt field and the intermediate types are alkaline trachyte and trahyandacites (Fig. 5a). On the $\mathrm{K}_{2} \mathrm{O}$ versus silica variation diagram (Peccerillo and Taylor, 1976), most volcanic rocks fall in the high-K calcalkaline and shoshonite fields (Fig. 5b); they show $\mathrm{A} / \mathrm{CNK}$ ratios varying between 1.38 and 1.01 , and $\mathrm{A} / \mathrm{NK}$ ratios between 2.98 and 1.35, indicative of a peraluminous tendency, although some basalts have $\mathrm{A} / \mathrm{CNK}$ ratios between 0.98 and $0.93 . \mathrm{Fe}_{2} \mathrm{O}_{3}$, $\mathrm{MgO}, \mathrm{TiO}_{2}, \mathrm{CaO}$ and $\mathrm{P}_{2} \mathrm{O}_{5}$ decrease with increasing silica. $\mathrm{Al}_{2} \mathrm{O}_{3}$ is fairly constant, while $\mathrm{K}_{2} \mathrm{O}$ and $\mathrm{Na}_{2} \mathrm{O}$ show a significant increase in the felsic members in comparison with abundances in the intermediate and mafic rocks. The $m g$ number $[(m g \#=100 \times \mathrm{Mg} / \mathrm{Mg}$ $\left.+\mathrm{Fe}^{2+}\right)$ ] ranges from 11.59 to 35.31 in the basalts, 1.19 to 2.96 in the trachytes and trachydacites, and among 0.47 to 8.28 in the rhyolites.

In the ratio $\mathrm{Zr} / \mathrm{TiO}$, versus $\mathrm{Nb} / \mathrm{Y}$ diagram (Winchester and Floyd, 1977), an effective discriminant for magmatic types, basic samples are classified as basalts, trahyandesites, and commandites/pantellerites, the majority of them lying on the limit between the subalkaline and alkaline fields, while andesites and rhyodacites/dacites, plotted within the subalkaline field (Fig. 5C).

\subsubsection{Basalts}

These rocks are enriched in $\mathrm{TiO}_{2}, \mathrm{Na}_{2} \mathrm{O}, \mathrm{K}_{2} \mathrm{O}$ and $\mathrm{P}_{2} \mathrm{O}$ and show higher of LILE (K, Rb, Ba), HFSE (Zr, Y) and REE (Table 1) contents in comparison with the values observed in the Ordovician tholeiitic basalts (Cisterna et al., 2010) (Figs. 6A and 7A). The average value of $m g \#$ is 22.03 for the Las Lozas basalts, much lower than the estimated $m g \#$ for primitive mantle-derived basaltic magmas (Talusani, 2010). In fact, the $m g \#$ numbers (from 11.5 to 35.3 ), and contents of $\mathrm{Ni}$ (21 to $101 \mathrm{ppm}$ ), $\mathrm{Cr}$ (23 to 131$)$ and $\mathrm{MgO}(2.1$ to $7.82 \%)$ are lower than the ones to be expected for basalts derived from a primitive mantle, an indication of more evolved compositions. Therefore, these basalts were probably modified by fractional crystallization and crustal assimilation processes during their ascent (De Paolo, 1981). They correspond on the other hand, high-Ti types with Ti/Y ratios ranging from 621.93 to $911.7, \mathrm{TiO}_{2}$ content between $2.58 \%$ and $4.53 \%$, characteristic of high-Ti basalts (Shellnutt and Jahn, 2011). They show an average $\mathrm{Fe}_{2} \mathrm{O}_{3} / \mathrm{TiO}_{2}$ ratio of 4.43 , also presenting abundances of trace elements compatible with high-Ti features (e.g., $\mathrm{Zr}$ between 160 to $462 \mathrm{ppm}, \mathrm{Nb}$ from 13 to $28.3 \mathrm{ppm}$, Hf from 3.75 to $6.9 \mathrm{ppm}$, and Th from 1.71 to $3.18 \mathrm{ppm}$ ). Their chondrite-normalized REE patterns (Fig. 6A) are rather flat, with $\mathrm{Sm} / \mathrm{Yb}_{\mathrm{N}}$ around 3.1-3.3 and with $\mathrm{La} / \mathrm{Yb}_{\mathrm{N}}$ around 5.7 to 6.7 , with a slight enrichment in LREE and no Eu anomaly, thus precluding fractionation of feldspars. The MORB-normalized pattern (Pearce, 1983; Fig. 7A) shows a slight enrichment in LILE $(\mathrm{K}, \mathrm{Rb}, \mathrm{Ba})$ and a significant depletion of $\mathrm{Sr}$, but also Th enrichment, with a slight depletion of $\mathrm{Nb}$ and $\mathrm{Ta}$ relative to the adjacent $\mathrm{Th}$ and $\mathrm{Ce} . \mathrm{Nb}$ and $\mathrm{Ta}$ anomalies are noted, as well as a moderate enrichment in LREE. These features are 
TABLE 1. CHEMICAL ANALYSES OF THE STUDIED VOLCANIC ROCKS FROM LAS LOZAS SECTION.

\begin{tabular}{|c|c|c|c|c|c|c|c|c|c|c|c|c|c|c|c|}
\hline $\begin{array}{c}\text { Sample } \\
\text { Major }\end{array}$ & $\begin{array}{c}\text { CG73 } \\
\text { oxides }\end{array}$ & $\begin{array}{c}\text { CG84 } \\
w t \%\end{array}$ & CG90 & CG95 & CG97 & CG98 & CG108 & CG110 & CG175 & CG176 & CG177 & CG66 & CG75 & CG94 & CG96 \\
\hline $\mathrm{SiO}$ & 69 & 75.49 & 77.12 & 45.6 & 76.19 & 63.51 & 63.82 & 46.15 & 42.83 & 75.64 & 76.27 & 65.64 & 74.5 & 49.97 & 47.63 \\
\hline $\mathrm{TiO}_{2}^{2}$ & 0.521 & 0.154 & 0.173 & 3.991 & 0.205 & 0.658 & 0.692 & 2.829 & 4.326 & 0.262 & 0.32 & 0.562 & 0.263 & 2.585 & 3.954 \\
\hline $\mathrm{Al}_{2} \mathrm{O}_{3}$ & 12.33 & 8.26 & 10.15 & 12.97 & 9.9 & 14.14 & 14.01 & 13.49 & 13.21 & 9.46 & 11 & 14.38 & 10.86 & 12.92 & 13.28 \\
\hline $\mathrm{Fe}_{2} \mathrm{O}_{3}$ & 6.44 & 6.87 & 3.15 & 15.39 & 4.72 & 7.94 & 7.48 & 13.57 & 16.86 & 6.03 & 3.97 & 7.18 & 3.6 & 14.89 & 15.26 \\
\hline $\mathrm{MnO}^{2} \mathrm{O}^{3}$ & 0.15 & 0.07 & 0.03 & 0.23 & 0.85 & 0.19 & 0.18 & 0.19 & 0.23 & 0.07 & 0.05 & 0.14 & 0.04 & 0.32 & 0.25 \\
\hline $\mathrm{MgO}$ & 0.25 & 0.11 & 0.11 & 4.43 & 0.45 & 0.16 & 0.24 & 7.82 & 4.78 & 0.03 & 0.34 & 0.091 & 0.04 & 2.1 & 4.18 \\
\hline $\mathrm{CaO}$ & 0.54 & 0.25 & 0.21 & 8.49 & 0.76 & 0.85 & 1.91 & 7.34 & 8.42 & 0.32 & 0.28 & 0.4 & 0.17 & 6.49 & 7.08 \\
\hline $\mathrm{Na}_{2} \mathrm{O}$ & 4.43 & 3.16 & 2.9 & 2.91 & 3.46 & 4.65 & 4.92 & 2.98 & 2.79 & 3.5 & 4.17 & 4.45 & 4.39 & 2.09 & 3.54 \\
\hline $\mathrm{K}_{2} \mathrm{O}$ & 4.32 & 3.95 & 4.79 & 2.31 & 3.51 & 5.38 & 5.01 & 1.44 & 2.15 & 3.25 & 3.5 & 6.1 & 3.61 & 4.75 & 2.42 \\
\hline $\mathrm{P}_{2} \mathrm{O}_{5}$ & 0.09 & 0.01 & 0.02 & 0.8 & 0.01 & 0.11 & 0.15 & 0.67 & 1.34 & 0.01 & 0.05 & 0.01 & 0.01 & 1.22 & 0.83 \\
\hline $\mathrm{LOI}^{2}$ & 0.46 & 0.38 & 0.5 & 2.17 & 0.36 & 1.28 & 0.56 & 2.94 & 2.36 & 0.16 & 0.4 & 0.63 & 0.363 & 2 & 2.13 \\
\hline Total & 98.53 & 98.7 & 99.15 & 99.21 & 99.65 & 98.87 & 98.97 & 99.42 & 99.29 & 98.74 & 100.35 & 99.64 & 97.84 & 99.33 & 100.55 \\
\hline Trace & elements & ppm & & & & & & & & & & & & & \\
\hline $\mathrm{Ba}$ & 917 & 158 & 192 & 569 & 115 & 195 & 940 & 383 & 429 & 92 & 148 & 218 & 88 & 726 & 596 \\
\hline $\mathrm{Hf}$ & 20.3 & 86 & 49.1 & 3.75 & 63.9 & 18.3 & 13.3 & 4.45 & 4.63 & 64 & 44.6 & 15 & 49 & 6.9 & 4.91 \\
\hline $\mathrm{Nb}$ & 70 & 212 & 145 & 17.5 & 94.5 & 91.6 & 51.1 & 18.3 & 28.3 & 177 & 128 & 69 & 124 & 15 & 13 \\
\hline $\mathrm{Zr}$ & 849 & 3,838 & 1,838 & 160 & 2,766 & 799 & 581 & 191 & 191 & 2,758 & 1,814 & 574 & 1,483 & 462 & 286 \\
\hline $\mathrm{Y}$ & 93 & 379 & 211 & 33 & 257 & 80.4 & 78 & 28 & 41.7 & 263 & 185 & 78 & 163 & 35 & 26 \\
\hline $\mathrm{Sr}$ & 41 & 18 & 17 & 478 & 58 & 97 & 57 & 284 & 345 & 34.3 & 20 & 10 & 17 & 153 & 512 \\
\hline $\mathrm{Rb}$ & 83 & 92 & 123 & 65 & 73 & 125 & 98 & 39 & 103 & 68 & 75 & 91 & 78 & 170 & 116 \\
\hline $\mathrm{Cs}$ & 0.73 & 0.19 & 0.39 & 1.69 & 0.57 & 2.73 & 2.03 & 0.55 & 2.45 & 0.28 & 0.26 & 1.28 & 0.51 & 5.49 & 2.08 \\
\hline $\mathrm{Ni}$ & 4 & 6 & 4 & 21 & 4 & 3 & 4 & 101 & 39 & 4 & 5 & - & 4 & - & 2 \\
\hline Co & 25 & 5 & 5 & 36 & 29 & 28 & 24 & 54 & 41 & 5 & 5 & 0.53 & 6 & 28 & 49 \\
\hline $\mathrm{Cr}$ & 10 & 12 & 12 & 30 & 12 & 4 & 12 & 131 & 51 & 4 & 12 & 3.71 & 3 & 0.5 & 23 \\
\hline Th & 17.3 & 55.7 & 45.4 & 1.71 & 43.6 & 7.78 & 10.5 & 1.75 & 1.97 & 38.7 & 30.9 & 10.4 & 34.5 & 3.18 & 2.25 \\
\hline $\mathrm{U}$ & 3.7 & 12.8 & 10.2 & 0.54 & 9.82 & 2.28 & 2.88 & 0.44 & 0.7 & 10.8 & 8.54 & 1.58 & 7.4 & 0.43 & 0.48 \\
\hline $\mathrm{Ta}$ & 4.41 & 17.9 & 9.97 & 0.88 & 16.2 & 7.24 & 3.1 & 0.89 & 1.95 & 12.9 & 10.5 & 4.61 & 9.73 & 1.7 & 1.47 \\
\hline $\mathrm{Sc}$ & 13 & 13 & 13 & 37 & 3 & 5 & 13 & 27 & 33 & 3 & 13 & 1.8 & 0.22 & 35.9 & 35 \\
\hline $\mathrm{Zn}$ & 139 & 593 & 217 & 119 & 222 & 160 & 119 & 115 & 135 & 247 & 206 & 189.2 & 171.7 & 126 & 126 \\
\hline $\mathrm{Ga}$ & 33 & 42 & 36 & 21 & 22 & 38 & 35 & 19 & 23 & 44 & 44 & - & - & - & - \\
\hline V & 14 & 8 & 12 & 12 & 16 & 8 & 9 & 226 & 286 & 2 & 18 & 35 & 18 & 28 & 361 \\
\hline $\mathrm{La}$ & 94.2 & 359 & 86.8 & 21.6 & 250 & 83.6 & 70.1 & 23.2 & 29.6 & 287 & 90.2 & 77.5 & 122.5 & 42.9 & 32.8 \\
\hline $\mathrm{Ce}$ & 208 & 768 & 198 & 48.4 & 450 & 164 & 149 & 51 & 62.8 & 533 & 228 & 169 & 308 & 104.5 & 61.5 \\
\hline $\mathrm{Nd}$ & 96.7 & 335 & 102 & 30.9 & 236 & 93 & 73.4 & 31.3 & 42.1 & 269 & 100 & 90.6 & 135 & 80.4 & 44.2 \\
\hline $\mathrm{Sm}$ & 19.6 & 70.5 & 27.9 & 7.32 & 49.9 & 18.4 & 15.3 & 6.97 & 9.83 & 50.7 & 25.2 & 18.4 & 30.2 & 14.5 & 10.7 \\
\hline $\mathrm{Eu}$ & 3.49 & 3.93 & 0.28 & 3.33 & 1.09 & 1.74 & 4.37 & 2.54 & 3.98 & 1.97 & 0.86 & 2.79 & 1.43 & 6.23 & 4.13 \\
\hline Dy & 15.9 & 65.9 & 34.2 & 5.98 & 51.2 & 16.1 & 12.7 & 5.38 & 7.75 & 25.37 & 29.6 & 18.4 & 35.4 & 11.9 & 7.53 \\
\hline $\mathrm{Yb}$ & 8.97 & 35.8 & 19.7 & 2.56 & 30.7 & 9.2 & 6.73 & 2.35 & 3.06 & 29.4 & 17.8 & 8.9 & 18 & 4.66 & 3.72 \\
\hline $\operatorname{Pr}$ & 25 & 88.2 & 26.3 & 6.84 & 59.5 & 21.7 & 18.5 & 7.18 & 8.81 & 67.2 & 26.1 & - & - & - & - \\
\hline $\mathrm{Gd}$ & 18.2 & 68.2 & 31.6 & 7.63 & 39.9 & 14.8 & 14 & 6.87 & 9.05 & 45.4 & 27.4 & - & - & - & - \\
\hline $\mathrm{Tb}$ & 2.77 & 11.2 & 5.67 & 1.09 & 7.99 & 2.63 & 2.22 & 0.98 & 1.32 & 8.66 & 4.9 & 2.89 & 5.32 & 1.93 & 1.35 \\
\hline Но & 3.37 & 14.2 & 7.48 & 1.21 & 11.1 & 3.24 & 2.68 & 1.1 & 1.6 & 10.5 & 6.67 & - & - & - & - \\
\hline $\mathrm{Er}$ & 9.09 & 38.4 & 20.4 & 3 & 27 & 7.73 & 7.06 & 2.74 & 3.77 & 26.6 & 18.2 & - & - & - & - \\
\hline $\mathrm{Tm}$ & 1.41 & 5.85 & 3.21 & 0.44 & 4.14 & 1.16 & 1.09 & 0.4 & 0.47 & 3.97 & 2.91 & - & - & - & - \\
\hline $\mathrm{Lu}$ & 1.34 & 5.06 & 2.76 & 0.38 & 4.64 & 1.56 & 1 & 0.35 & 0.48 & 4.38 & 2.49 & 1.37 & 2.63 & 0.725 & 0.49 \\
\hline
\end{tabular}



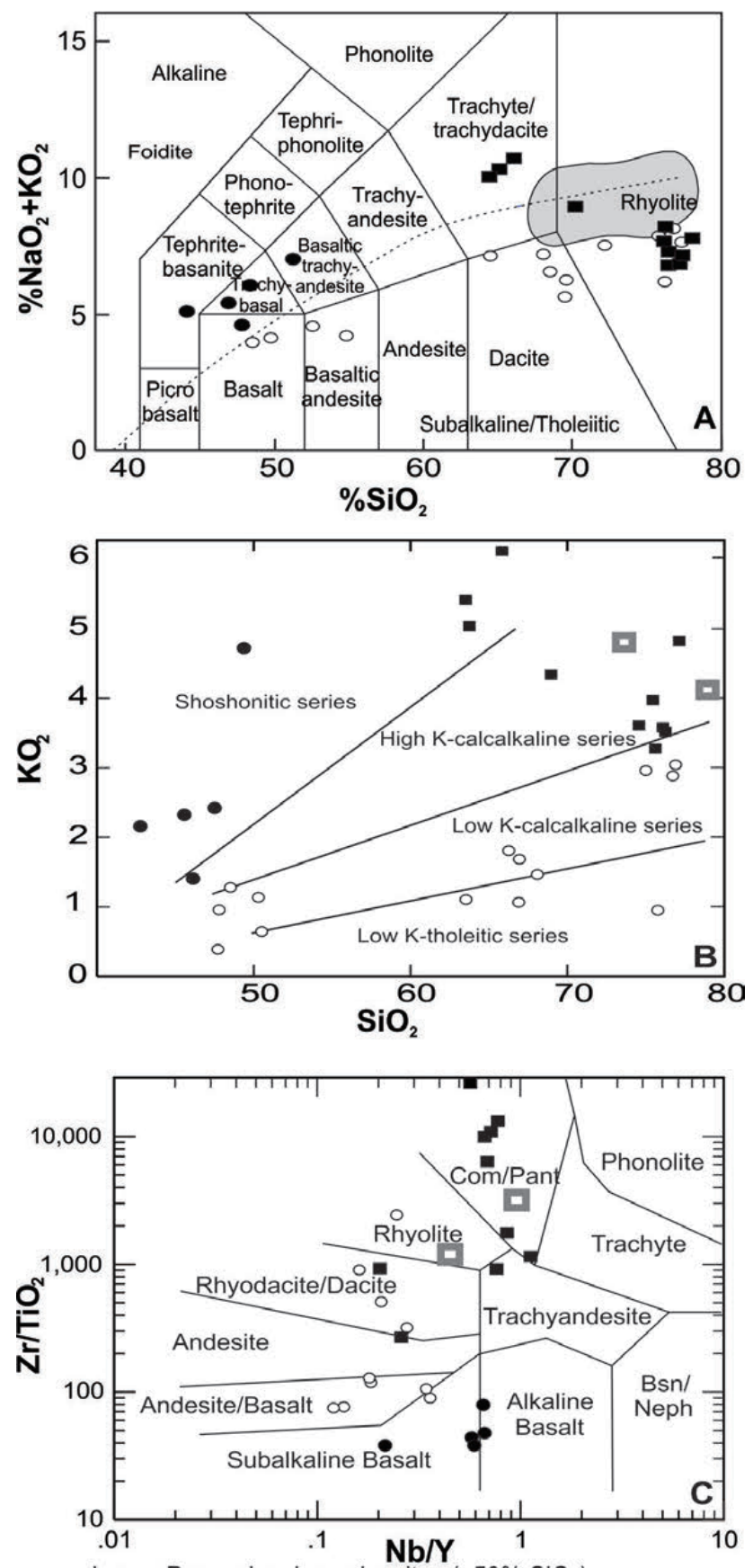

- Lower Pennsylvanian volcanites $\left(>50 \% \mathrm{SiO}_{2}\right)$

- Lower Pennsylvanian volcanites $\left(<50 \% \mathrm{SiO}_{2}\right)$

- Mississippian volcanites analyzed by Martina et al. (2011)

o Ordovician volcanites

Grey field represent Carboniferous Eastern Sierras

Pampeanas granites (Grosse et al., 2009, Dahlquist et al., 2010 and Alasino et al., 2012)

FIG. 5. Diagrams from the Las Lozas volcanic rocks: A. TAS (Le Bas et al., 1986); B. $\mathrm{SiO}_{2}$ versus $\mathrm{K}_{2} \mathrm{O}$ (Peccerillo and Taylor, 1976); and C. Diagram $\mathrm{Zr} / \mathrm{TiO}_{2}$ versus $\mathrm{Nb} / \mathrm{Y}$ (Winchester and Floyd, 1977). The boundary between alkaline and subalkaline series (dashed line in a) is after Irvine and Baragar (1971). 

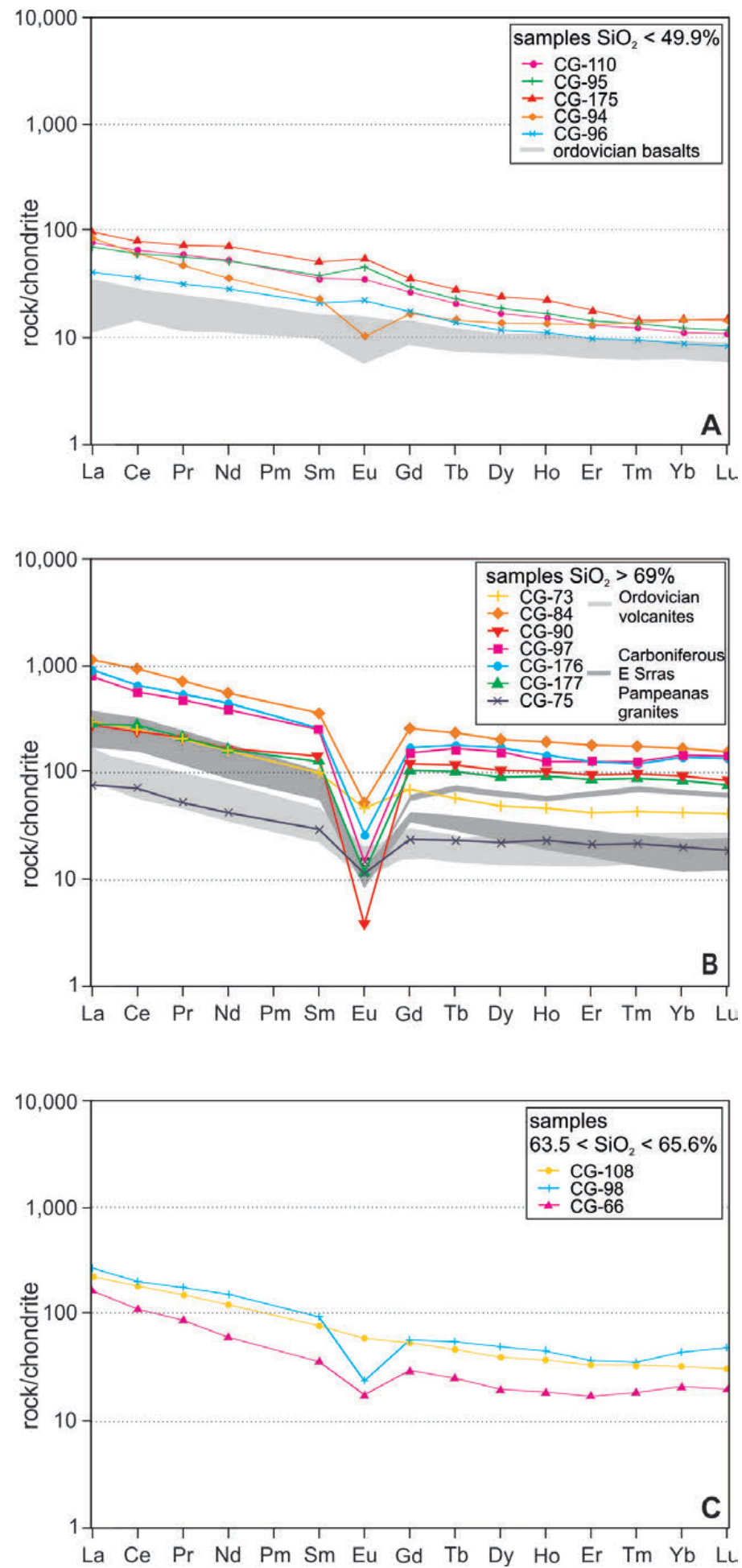

FIG. 6. Chondrite-normalized (after Boynton, 1984) REE diagram of the volcanic rocks of Las Lozas section; $\mathbf{A}$. samples $<49,9 \% \mathrm{SiO}_{2}$; B. samples $>69 \% \mathrm{SiO}_{2}$; C. samples $63,5 \%-65,5 \% \mathrm{SiO}_{2}$. Gray shaded areas correspond to Ordovician volcanic rocks of Famatina reported by Cisterna et al. (2010) and to Carboniferous E Sierras Pampeanas granites (Grosse et al., 2009; Dahlquist et al., 2010). 

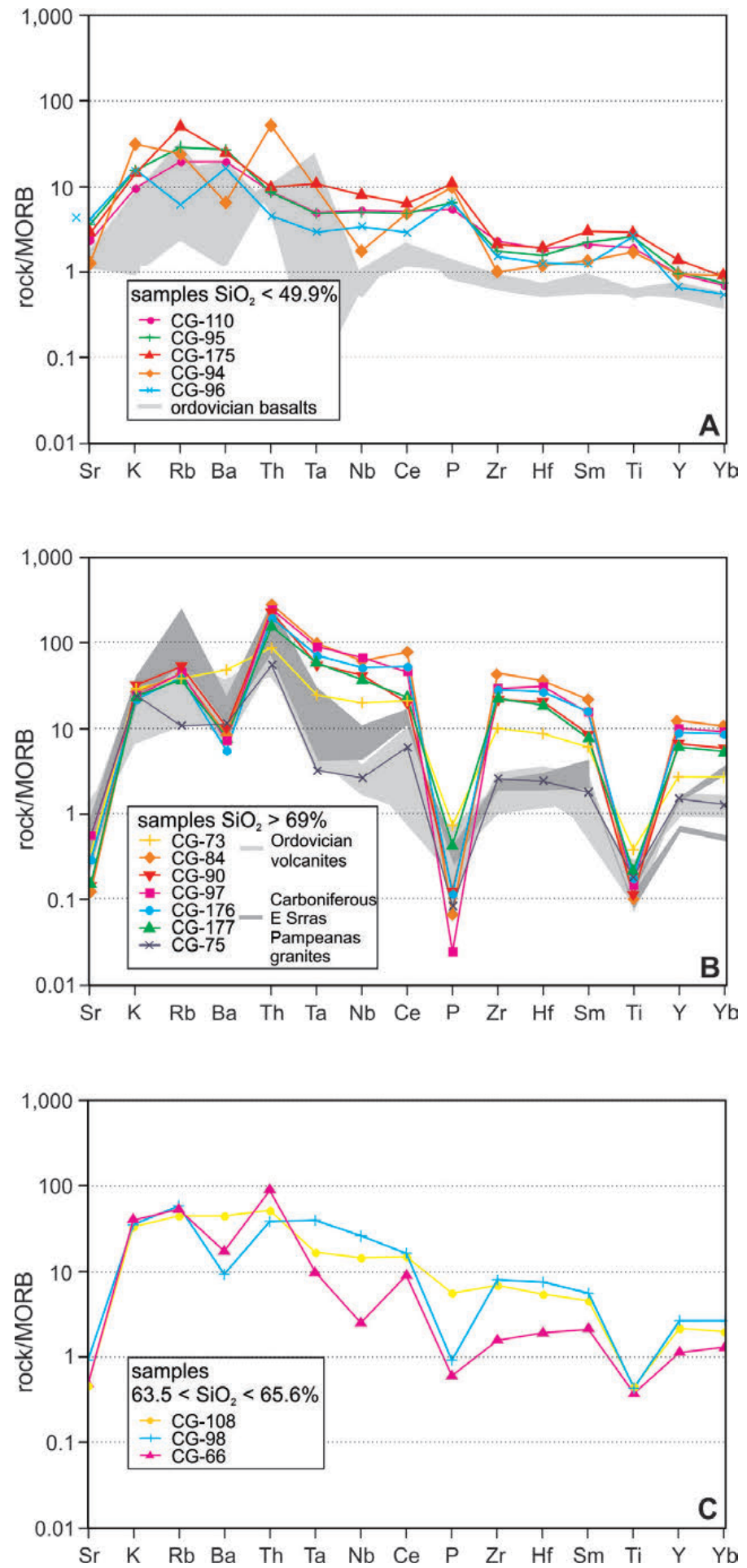

FIG. 7. Multi-element variation diagram, normalized to MORB (Pearce, 1983), of the studied volcanic rocks of Las Lozas section: A. samples $<49,9 \% \mathrm{SiO}_{2}$; B. samples $>69 \% \mathrm{SiO}_{2} ;$ C. samples $63,5 \%-65,5 \% \mathrm{SiO}_{2}$. Gray shaded areas correspond to Ordovician volcanic rocks of Famatina reported by Cisterna et al. (2010) and to Carboniferous E Sierras Pampeanas granites (Grosse et al., 2009; Dahlquist et al., 2010) . 
comparable to patterns shown by transitional MORB basalts and within-plate tholeiites from attenuated continental terranes (Pearce, 1996), including contribution of a mantle source affected by crustal contamination during the genesis of magmas. In the case of Ordovician basalts the $\mathrm{Nb}$ and $\mathrm{Ta}$ depletion relative to $\mathrm{Th}$ and $\mathrm{Ce}$ is marked giving indication of a subduction component (Fig. 7A).

In the tectonic triangular discrimination diagram $\mathrm{Zr} / 4-\mathrm{Nbx} 2-\mathrm{Y}$ (Meschede, 1986) the basalts also show a transitional position within the intraplate alkali basalt field (AII), near the limit of the plume-enriched MORB field (B=PMORB). Only one sample lies in the volcanic arc basalt field ( $\mathrm{D}=\mathrm{VAB}$, Fig. $8 \mathrm{~A})$. On the Th-Hf/3-Ta and $\mathrm{Th}-\mathrm{Zr} / 17-\mathrm{Nb} / 16$ diagrams (Wood, 1980; Fig. 8B, C), these samples plot within the E-type MORB and WPT fields. The within-plate characteristics are also pointed out by the $\mathrm{La} / \mathrm{Ta}$ (average of 22.66) and $\mathrm{Ba} / \mathrm{Ta}$ (average of 433.58) ratios. Meanwhile, the Ordovician basalts plot in the volcanic arc and PMORB fields in the first diagram and in the volcanic arc fields in the other two.

\subsubsection{Rhyolites and trachytes}

The high silica rocks show an average $\mathrm{SiO}_{2}$ content of $74.89 \%$ (rhyolites) and $64.32 \%$ (trachytes) and $m g$ numbers of 3.64 for rhyolites and 2.0 for trachytes and contents of $\mathrm{Al}_{2} \mathrm{O}_{3}=10.28 \%, 14.18 \%$, $\mathrm{TiO}_{2}=0.27 \%, 0.64$, and $\mathrm{Na}_{2} \mathrm{O}+\mathrm{K}_{2} \mathrm{O}=7.59 \%, 10.2 \%$ respectively. Some trace elements such as $\mathrm{Cr}, \mathrm{Y}$ and $\mathrm{Zr}$ increase with the increase in silica content $(\mathrm{Cr}$, from $6.6 \mathrm{ppm}$ in trachytes to $9.3 \mathrm{ppm}$ in rhyolites; Y, from 78.8 to $185.2 \mathrm{ppm}$; Zr, from 629 to $2,162.7$ $\mathrm{ppm}$ ), while $\mathrm{Ba}, \mathrm{Rb}$ and $\mathrm{Sr}$ tend to decrease (Ba from 448.6 in trachytes to $247 \mathrm{ppm}$ in rhyolites; $\mathrm{Rb}$ from 102 to $86.1 \mathrm{ppm}$; Sr from 59 to $29.3 \mathrm{ppm}$ ).

The chondrite-normalized patterns for rhyolites display an enrichment in LREE $\left(\mathrm{La} / \mathrm{Yb}_{\mathrm{N}}=3.0\right.$ to 6.8) relative to the HREE with $\mathrm{Sm} / \mathrm{Yb}_{\mathrm{N}}=1.5$ to 2.1 (Fig. 6B). They show a strong Eu anomaly $(\mathrm{Eu} /$ $\mathrm{Eu}^{*}=0.03$ to 0.53 ), an indication of significant feldspar fractionation, probably during ascent. In contraposition the Carboniferous Eastern Sierras Pampeanas granites show in most cases high enrichment in $\operatorname{LREE}\left(\mathrm{La} / \mathrm{Yb}_{\mathrm{N}}=8.5\right.$ to 13.3$)$ and higher HREE with $\mathrm{Sm} / \mathrm{Yb}_{\mathrm{N}}=2.5$ to 4.1. A MORB-normalized pattern shows in the rhyolites an enrichment in some LILE ( $\mathrm{Rb}$ and $\mathrm{K}$ ), but also a significant depletion in $\mathrm{Sr}$ and $\mathrm{Ba}$, the last parameters indicating probably also fractionation of feldspars (Fig. 7b). Th and Ce
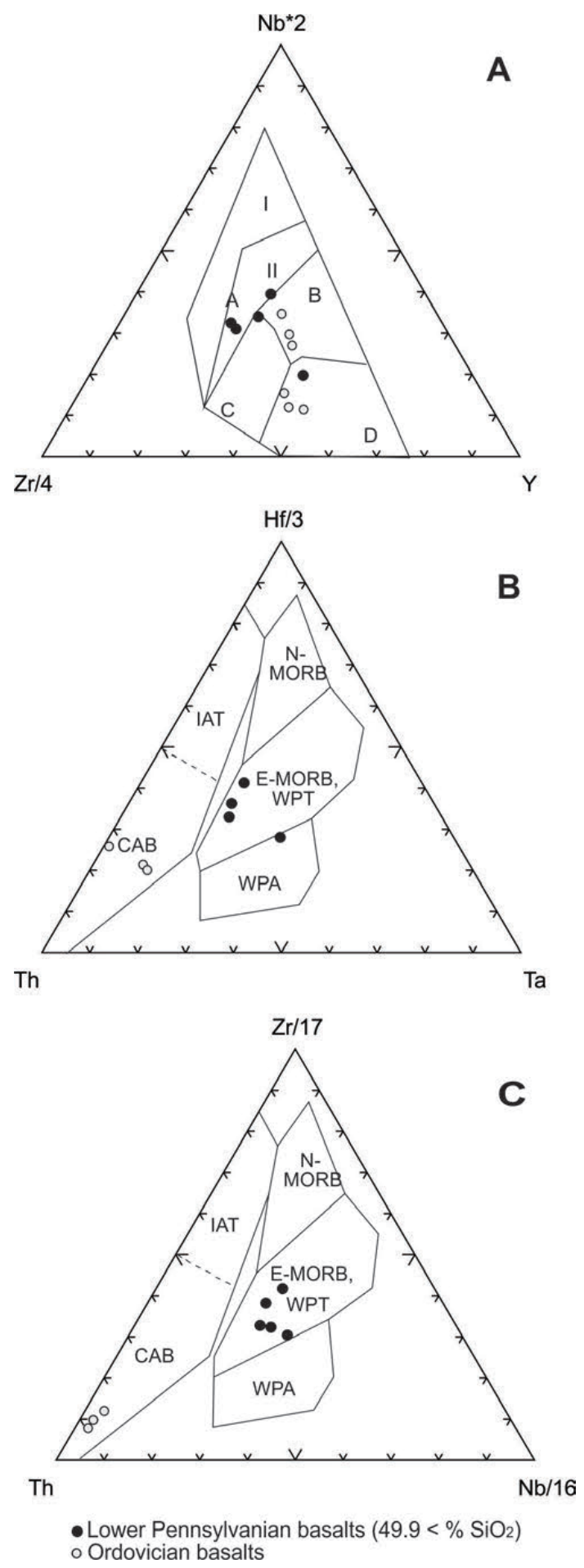

FIG. 8. Basalts from Las Lozas section and Ordovician basalts from Famatina (Cisterna et al., 2010) plotted in the tectonic discrimination diagrams: A. Zr/4-Nbx2-Y (Meschede, 1986); B. Th-Hf/3-Ta and C. Th-Zr/17/Nb/16 diagrams (Wood, 1980). 
are relatively enriched, in comparison with $\mathrm{Nb}$ and $\mathrm{Ta}$, and is observed enrichment in $\mathrm{Zr}$, Hf, Sm, Y and $\mathrm{Yb}$, as well as strong negative anomalies in $\mathrm{P}$ and $\mathrm{Ti}$, signs of interaction of a mantle source with the crust, Meanwhile the Carboniferous Eastern Sierras Pampeanas granites show a lower negative anomaly of $\mathrm{Ta}$ and $\mathrm{Nb}$ and less enrichment in $\mathrm{Zr}, \mathrm{Hf}, \mathrm{Sm}$, $\mathrm{Y}$ and $\mathrm{Yb}$, with minor negative anomalies in $\mathrm{P}$ and $\mathrm{Ti}$, pointing to a less interaction with the mantle.

The chondrite-normalized pattern for the intermediate rocks shows a slight enrichment in $\operatorname{LREE}\left(\mathrm{La} / \mathrm{Yb}_{\mathrm{N}}=5.9-7.1\right)$ relative to the HREE, with $\mathrm{Sm} / \mathrm{Yb}_{\mathrm{N}}=2.1-2.3$, and practically no Eu anomaly $(\mathrm{Eu} /$ $\mathrm{Eu}^{*}=0.32-0.91$ ) (Fig. 6c). The MORB normalized pattern for these rocks displays an enrichment in $\operatorname{LILE}(\mathrm{K}, \mathrm{Rb})$ and a significant depletion in $\mathrm{Sr} ; \mathrm{Ba}$ is variable (Fig. $7 \mathrm{c}$ ). $\mathrm{Th}, \mathrm{Ta}, \mathrm{Nb}$ and $\mathrm{Ce}$ are also moderately enriched, as well as $\mathrm{Zr}$, Hf, Sm, $\mathrm{Y}$ and $\mathrm{Yb}$; $\mathrm{Nb}$ contents are variable, and may present negative anomalies. Ti and $\mathrm{P}$ also show depletion and negative values, but less pronounced than the ones found in the rhyolite members. The intermediate volcanic rocks present characteristics that lie between those observed in basalts and rhyolites.

Both rhyolites and trachytes show very low $\mathrm{Th} /$ Ta ratios (1.07 to 4.55), coinciding with values found in within-plate zones (WPVZ; Gorton and Schandl, 2000). The within-plate nature of these magmas is

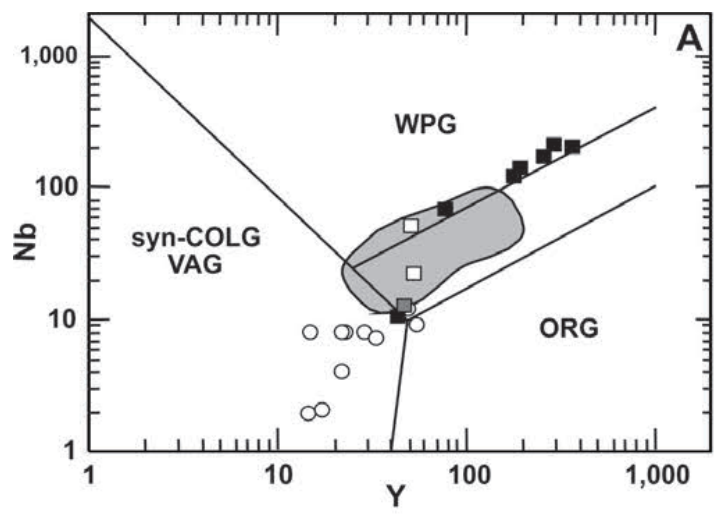

- Carboniferous volcanites $\left(>69 \% \mathrm{SiO}_{2}\right)$

o Ordovician volcanites (Cisterna et al., 2010)

Grey field represent Carboniferous Eastern Sierras Pampeanas granites (Dahlquist et al., 2010, Grosse et al., 2009) also indicated by the $\mathrm{Th} / \mathrm{Yb}(1.17-2.3)$ and $\mathrm{Ta} / \mathrm{Yb}$ ratios ( 0.51 on average; cf. Gorton and Schandl, 2000), consistent with the results observed in the tectonic discrimination diagrams of Pearce et al. (1984) (Fig. 9a, b). In these last referred diagrams the Carboniferous Eastern Sierras Pampeanas granites and rhyolites, as Cazadero Grande rhyolites, plot in the within-plate field, in contraposition to Ordovician volcanic rocks framed in the field of volcanic arcsyncollision granites (Figs. 9a and b).

\subsubsection{Strontium and neodymium isotopes}

${ }^{87} \mathrm{Sr} /{ }^{86} \mathrm{Sr}$ isotopic ratios of selected samples from Lozas Valley profile as: CG-97 (rhyolite) and CG-176 (vitrophyre) were determined as well as the $\mathrm{Sm}-\mathrm{Nd}$ ratios for basalt sample CG-175. The analytical work was done in order to pinpoint an additional information on the magma source of the volcanism recorded in Las Lozas valley, for which has been recently obtained an U-Pb SHRIMP age of $320 \mathrm{Ma}$ and Hf data (Zapettini et al., 2015) that signalize a juvenile sources of Cryogenian age for that volcanism. The ${ }^{87} \mathrm{Sr} /{ }^{86} \mathrm{Sr}$ and ${ }^{147} \mathrm{Sm} /{ }^{144} \mathrm{Nd}$ determined ratios are also supporting data to counterpose Mississippian of lower Pennsylvanian magmatism.

The calculated $\mathrm{Sr}$ initial ratios for the rhyolites CG$97\left({ }^{87} \mathrm{Sr} /{ }^{86} \mathrm{Sr}=0.70164\right)$ and $\mathrm{CG}-176\left({ }^{87} \mathrm{Sr} r{ }^{86} \mathrm{Sr}=0.70287\right)$ and basalt sample CG-175 $\left({ }^{87} \mathrm{Sr} /{ }^{86} \mathrm{Sr}=0.70479\right)$

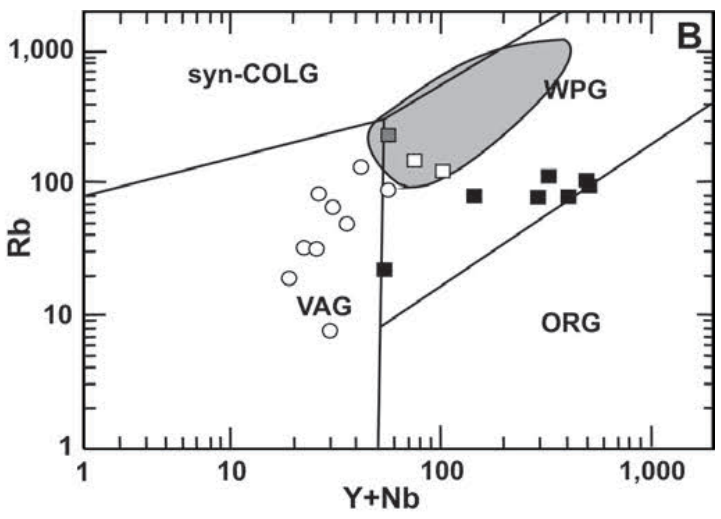

- Rhyolites analyzed by Martina et al. (2011) $\square$ Rhyolite analyzed by Dahlquist et al. (2008)

FIG. 9. Y versus $\mathrm{Nb}$ and $\mathrm{Y}+\mathrm{Nb}$ versus $\mathrm{Rb}$ tectonic discrimination diagrams (Pearce et al., 1984) for the analyzed rhyolites. The Lower Pensylvannian rocks and Carboniferous E Sierras Pampeanas granites plot in the within plate granites field (WPG) unlike the Ordovician samples, which mostly plot in the volcanic arc field (VAG). Gray shaded areas are the Ordovician felsic volcanics of Famatina. 
for an age of $320 \mathrm{Ma}$, considering U-Pb SHRIMP age determined in the study section, are very low (Table 2 ) and could correspond to a mantle source indicating a clear predominance of a juvenile component, in agreement with previous conclusions of Zapettini et al. (2015).

Likewise the positive value $\varepsilon \mathrm{Nd}_{(320 \mathrm{Ma})}=+3.11$ of the CG-175 basalt (Table 2) suggests that the parental basaltic magma was originated within the asthenospheric mantle

Moreover if the $\mathrm{Sr}$ and $\mathrm{Nd}$ parameters of the CG-175 basalt are plotted in a $\varepsilon_{(\mathrm{Nd})}$ versus ${ }^{87} \mathrm{Sr} /{ }^{86} \mathrm{Sr}$ diagram, its parental magma would be located close to the Mantle array (Fig. 10). Moreover, the Sm$\mathrm{Nd}$ model $\mathrm{T}_{\mathrm{DM}}$ age of 774.6 Ma indicated above is an evidence of assimilation of a minor amount of reworked material during the rise of the magma through the continental crust.

In comparison, $\mathrm{Sm}-\mathrm{Nd}$ isotopic analyses of the rhyolites from the Cazadero Grande region suggest a crustal source with some juvenile input, showing $\varepsilon \mathrm{Nd}_{(\mathrm{t})}$ between -2.91 and -0.3 , and $\mathrm{T}_{\mathrm{DM}}$ ages between 1.09 and $1.1 \mathrm{Ga}$ (Martina et al., 2011). Similar conclusions can be drawn (Fig. 10) from data of Sierras Pampeanas Carboniferous granites with $\varepsilon \mathrm{Nd}_{(\mathrm{t})}$ between -0.6 and -3.6 and $\mathrm{T}_{\mathrm{DM}}$ ages of 1.2 to $1.4 \mathrm{Ga}$, (Groose et al., 2009; Dahlquist et al., 2013) .

\section{Disscusion}

The distinctive characteristics of the Las Lozas volcanic sequence formed predominantly by rhyolites, with basalts and intermediate rocks as minor members give indications of the nature of the components, emplacement and environmental conditions. In this regard the association, within the acid members, of porphyritic and vitrophyric lavic rhyolites with their volcanoclastic breccias (autoclastic lavas; monomictic rhyolite and vitrophyre breccias) is consistent with the eruption mechanism of central lavas domes, consisting of a massive and coherent central part and crumbling outer domains, all mobilized to form extensive flows that resulted in the deposition of large tabular bodies of intermingled coherent and brecciated members. The dominance of rhyolitic lithic clasts in the polymictic breccias lithofacies suggests explosive eruptions that destroyed rhyolite lava domes. In some cases the breccia facies may be inferred that are above or very close to their source vents. The matrix of these breccias, showing spherulitic and granophyric textures, flow banded compositional structures with abundant glass and perlitic fragmentation may suggest high temperatures during their development (cf. Allen et al., 2008).

Basalts, together with the equivalent breccias ( $10 \%$ of the mapped section) are present as concordant lava flows, generally displaying autoclastic facies at their margins indicating locally high strain rates in an already more brittle lava body during continuous effusion (cf. McPhie et al., 1993). Trachytes to trachydacites and equivalent breccias show similar characteristics.

The association in the stratigraphic column of rhyolites with their volcanoclastic breccias, followed by minor basaltic and intermediate lavas suggest episodic eruption pulses triggering instabilities in the volcanic edifices and degradation of their flanks, with emission of lava and breccia flows and concomitant

TABLE 2. Rb-Sr AND Nd-Sm ANALYTICAL DATA OF FOUR SELECTED SAMPLES FROM THE STUDIED PROFILE (SEE FIGURE 2 FOR LOCATION).

\begin{tabular}{|c|c|c|c|c|c|c|c|c|c|c|c|}
\hline Sample & & $\begin{array}{l}\text { Vhole } \\
\text { rock }\end{array}$ & $\begin{array}{c}\text { Lab } \\
\text { number }\end{array}$ & \multicolumn{2}{|c|}{$\mathbf{R b}, \mathbf{p p m}$} & $\mathrm{Sr}, \mathrm{ppm}$ & ${ }^{87} \mathbf{R b} /{ }^{86} \mathrm{Sr}$ & $2 \sigma$ error & ${ }^{87} \mathrm{Sr} /{ }^{86} \mathrm{Sr}$ & $2 \sigma$ error & $\begin{array}{l}\left({ }^{87} \mathrm{Sr} /{ }^{86} \mathrm{Sr}\right)_{0} \\
\text { for } 320 \mathrm{Ma}\end{array}$ \\
\hline CG-175 & & Basalt & 5664 & 103.0 & & 345.0 & 0.864 & 0.026 & 0.708526 & 0.00006 & 0.70479 \\
\hline CG-176 & Vitı & ophyre & 15946 & 64.39 & & 32.59 & 5.730 & 0.045 & 0.728970 & 0.00004 & 0.70287 \\
\hline CG-97 & & yolite & 15947 & 80.6 & & 57.90 & 4.037 & 0.119 & 0.720024 & 0.00004 & 0.70164 \\
\hline Sample & $\begin{array}{c}\text { Whole } \\
\text { rock }\end{array}$ & $\begin{array}{c}\text { Lab } \\
\text { number }\end{array}$ & Sm,ppm & $\begin{array}{l}\text { Nd, } \\
\text { ppm }\end{array}$ & $\begin{array}{l}{ }^{147} \mathrm{Sm} / \\
{ }^{144} \mathrm{Nd}\end{array}$ & $\begin{array}{c}2 \sigma \\
\text { error }\end{array}$ & $\begin{array}{l}{ }^{143} \mathrm{Nd} / \\
{ }^{144} \mathrm{Nd}\end{array}$ & $\begin{array}{c}2 \sigma \\
\text { error }\end{array}$ & zero) \&Nd (3 & ( Ma) $\mathrm{f}^{\mathrm{Sm}-\mathrm{Nd}}$ & $\mathrm{T}_{\mathrm{DM}}(\mathrm{Ma})$ \\
\hline CG-175 & Basalt & 5664 & 9.830 & 42.100 & 0.4412 & 0.00002 & 0.512681 & 0.00001 & {$[+3$} & {$[-0.28]$} & 774.6 \\
\hline
\end{tabular}

(1) CG-97 - porphyritic rhyolite; (2) CG-176 - vitrophiric rhyolitic lava; (3) CG-175 - massive basalt. 


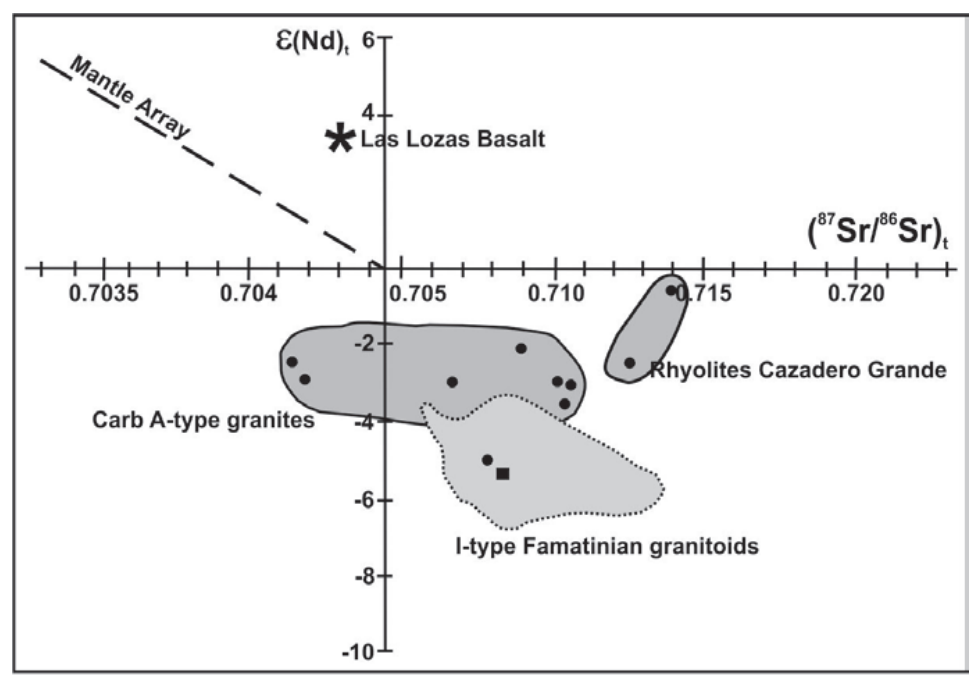

FIG. 10. $\varepsilon N d$ versus $\left({ }^{87} \mathrm{Sr} /{ }^{86} \mathrm{Sr}\right) t$ for las Lozas Basalt, rhyolites from Cazadero Grande, Carboniferous E Sierras Pampeanas granites and I type Famatinian granitoids. Data from Pankhurst et al. (1998), Dahlquist and Galindo (2004), Dahlquist et al. (2010), Martina et al. (2011).

collapse of the central lava domes. Although the vent sources for these lavas have yet to be identified. By other terranes, Allen and McPhie (2002) suggested that widespread outflow would be promoted by eruption from several vents along a fissure rather than from point-source vents, a relationship that is well demonstrated in flood basalt provinces (e.g., Self et al., 1996).

From a chemical point of view, the Las Lozas rocks plot in diagrams in the subalkaline/tholeiitic (rhyolites), alkaline basalts (basalts) and alkaline (trachytes) fields. They are mainly peraluminous, with the exception of a few metaluminous basalts.

The acid terms show chemical affinities with the Mississippian volcanic rocks that outcrop in the Cazadero Grande area and with the Carboniferous Eastern Sierras Pampeanas granites, showing all mainly a subalkaline trend (e.g., Fig. 5).

In regard to the Ordovician volcanic succession, they display a subalkaline trend, with medium to low K and also reach the tholeitic field (Fig. 5); the members basic are characterized by their low content of Ti.

The geochemical characteristics of the basalts are comparable to those of transitional MORB rocks and within-plate tholeiitic basalts from attenuated continental margins, where their mantle source is affected by crustal contamination. Moreover, the average $m g$ numbers, as well as the $\mathrm{Ni}$ and $\mathrm{Cr}$ contents, are much lower than those to be expected from basalts derived from a primitive mantle and they indicate a more evolved magma type, subjected to fractional crystallization and interaction with crustal material.

In the case of Ordovician basalts they form volcanic arc tholeiitic and MORB series. Such features indicate geotectonic environments linked to marginal basins (Cisterna et al., 2010). In addition their Zr-Ti-Y contents suggest a highly depleted mantle as their source but the enrichments in $\mathrm{Cs}, \mathrm{Rb}$, $\mathrm{Ba}$ and $\mathrm{Th}$ and negative anomaly of $\mathrm{Nb}$ in relation to Th and Ce reflect a subduction component and/ or crustal assimilation processes.

The geochemical features of the rhyolites are those of within-plate magmas, and their composition suggest a derivation from continental crustal material with mantle source interaction or a juvenile essentially mantle derived crust. The two rhyolite samples from Cazadero Grande presented by Martina et al. (2011), as the Carboniferous Eastern Sierras Pampeanas granites show geochemical affinities with Las Lozas rhyolites in the $\mathrm{Y}$ versus $\mathrm{Nb}$ and $\mathrm{Y}+\mathrm{Nb}$ versus $\mathrm{Rb}$ tectonic discrimination diagrams (Pearce et al., 1984) plotting in the within plate granites field (Fig. 9). Meanwhile the acid Ordovician volcanic rocks lies in the volcanic arc field (VAG).

Calculated ${ }^{87} \mathrm{Sr} /{ }^{86} \mathrm{Sr}$ initial ratios of 0.70164 0.70287 for an age of $320 \mathrm{Ma}$ for the rhyolites of 
the Las Lozas section suggest a clear predominance of a juvenile component. This is in contrast with the data obtained for the Cazadero Grande Mississippian rhyolites, exhibiting ${ }^{87} \mathrm{Sr} /{ }^{86} \mathrm{Sr}$ initial ratios of 0.71433 to 0.71233 for an age of $345 \mathrm{Ma}$ (Martina et al., 2011), and for coeval Sierras Pampeanas granites with ${ }^{87} \mathrm{Sr} /{ }^{86} \mathrm{Sr}$ initial ratios of 0.7044 to 0.7114 for an age of 345-354 Ma (Dahlquist et al.,2010). The last two magma types were probably extracted from a strongly enriched reservoir with negligible mantle contributions. It is also possible to differentiate the Pennsylvanian Las Lozas rocks from the Mississippian Cazadero Grande volcanism and the coeval Sierras Pampeanas A-granites in terms of their source, since the $\varepsilon \mathrm{Nd}_{(\mathrm{t})}=+3.11$ in a Las Lozas basalt suggests that its parental magma originated within the asthenospheric mantle. In contrast, the equivalent data from Cazadero Grande (e.g., $\varepsilon \mathrm{Nd}_{(\mathrm{t})}$ of- 0.3 and 2.91, Martina et al., 2011) and the main Carboniferous Sierras Pampeanas A-type granites (e.g., $\varepsilon \mathrm{Nd}_{(\mathrm{t})}$ of -0.5 and $-3,6$; Grosse et al., 2009, Dahlquist et al., 2013) seem to indicate a crustal source with some juvenile input.

Few isolated cases in a transect at $27^{\circ} 30^{\prime} \mathrm{S}$ show a greater contribution of juvenil material in their generation as Cerro La Gloria (353 Ma), in the west of the Eastern Sierras Pampenas $\left(\varepsilon \mathrm{Nd}_{(\mathrm{t})}\right.$ between $+0,46$ and -0,58, Alasino et al., 2012) and Guandacolinos granite $\left(314 \mathrm{Ma}, \varepsilon \mathrm{Nd}_{(\mathrm{t})}\right.$ between +1.7 and $+0,6$, Varela et al., 2004) and Cerro Veladero plutons (311 Ma; $\varepsilon \mathrm{Nd}_{(\mathrm{t})}$ between $+1,15$ and $-0,8$, Cingolani et al.,1993), in the east of the Western Sierras Pampeanas. On this basis, Alasino et al. (2012) concluded that the Carboniferous granitic rocks show, in that section, a greater contribution of juvenile material of mantle character to the west.

\section{Conclusions}

Las Lozas Pennsylvanian volcanic succession belongs to a bimodal magmatic series represented by subalkaline/tholeiitic rhyolites and alkaline basalts and trachytes. The geochemical characteristics of the basalts are comparable to those of transitional MORB rocks and within-plate tholeiitic basalts from attenuated continental margins, where their mantle source is affected by crustal contamination. Alike the rhyolites show within-plate signature, suggesting a juvenile component of their magma source as well as interaction with crustal material or a juvenile essentially mantle derived crust. Their ${ }^{87} \mathrm{Sr} /{ }^{86} \mathrm{Sr}$ initial ratios of 0.70479 (basalt)-0.70164 (rhyolite) likewise the positive value $\varepsilon \mathrm{Nd}_{(320 \mathrm{Ma})}=+3.11$ of a basalt strengthen that origin for the magmas. Those characteristics point to post-orogenic geotectonic conditions, in a within-plate setting during a regional crustal heating phase, in response to extension of the crust and mantle upwelling. These conditions, as was proposed by Alasino et al. (2012) for Carboniferous A-type magmatism, could have occurred in an extensional ensialic region linked to an Andean type margin where the lithospheric mantle played a role in its generation. These authors and Dahlquist et al. (2013) propose that the juvenile contribution could be explained by detachment of the lithosphere That conditions contrast with active continental margin setting of the Ordovician volcanism recorded in the study region, which involves a major contribution of pre-exinting old crustal rocks without evident participation of the asthenospheric mantle. In that case their geochemical parameters set themselves up as useful tools for their distinction.

It is possible to establish besides, based on isotopic data, a clear difference in the origin of magmas between the volcanic succession of Las Lozas and the Misisisippian rhyolites of Cazadero Grande and the main coeval Sierras Pampeanas A-type granites. Those data, for the case of Las Lozas, denote a predominance of a juvenile component but affected by crustal contamination, meanwhile indicate that the last two magmatic groups of rocks were probably extracted from a strongly enriched reservoir with negligible mantle contributions.

Taking in account the age difference in the region between Mississippian and the Lower Pennsylvanian magmatism, this would indicate a change in the magma source consistent with a more pronounced extensional tectonic regime for the Lower Pennsylvanian. This assumption need to be considered together with the Alasino et al. (2012) observations along a transect at $27^{\circ} 30^{\prime}$ S, where the Carboniferous Eastern Sierras Pampeanas granitic rocks show, regardless of age, a greater contribution of juvenile material of mantle character to the west. Among these rocks, with a major juvenile component, are those of the Las Lozas succession as well the Cerro Gloria Granite, the eastern manifestations of the Carboniferous Eastern Sierras Pampeanas magmatism. From the foregoing emerges that the contribution of juvenile material could be continuously varied through time as due to varying lithospheric extension during these 
tectono-thermal event. However draws attention the concentration of rocks with greater juvenile contribution near the boundary of A-type and I type magmatic representatives, coincident with Western and Eastern basement blocks, suggesting that that area may have had an important role in detachment of the lithosphere and in the control of the magmatism.

In order to achieve a better definition of a model to discern, if extensional variation was coupled with areas of regional weakness in the control of the juvenil material upwelling, during the Carboniferous magmatism, is necessary to obtain additional geochemical, isotopic and geochronological data across the region.

Regardless of these considerations, the data presented of the Las Lozas succession confirm that Carboniferous magmas in the region, product from reworking of supra-crustal material with variable input of juvenile magmas, are undoubtedly linked to changes in the lithospheric extension.

\section{Acknowlegdments.}

This study was funded by the Agencia Nacional de Promoción Científica y Tecnológica (ANPCYT) grant PICT 7-8724 and Consejo Nacional de Investigaciones Científicas y Técnicas (CONICET) grant PIP $\mathrm{N}^{\circ} 5115$. Additional support was provided by the Secretaria de Ciencia y Tecnología at the Universidad Nacional de Tucumán (CIUNT) 26/G410 and Secretaría de Ciencia y Técnica y Estudios Regionales at the Universidad Nacional de Jujuy (SECTER-UNJU) 08/E015 Projects. The São Paulo Science Foundation FAPESP is thanked for providing financial support for laboratory work (chemical and isotopic data) performed at the Instituto de Geociências, USP (grant to H.H.U.).We thank C. Mpodozis and V. Maksaev for their constructive reviews that significantly improved the manuscript and L.E. Lara for his suggestions and editorial assistance.

\section{References}

Alasino, P.H.; Dahlquist, J.A.; Pankhurst, R.J.; Galindo, C.; Casquet, C.; Rapela, C.W.; Larrovere, M.; Fanning, C.M. 2012. Early Carboniferous sub to mid-alkalinemagmatism in the Easter Sierras Pampeanas, NW Argentina: a record of crustal growth by the incorporation of mantle-derived material in an extensional setting. Gondwana Research 22: 992-1008. doi: dx.doi.org/10.1016/j.gr.2011.12.011.
Allen, S.R.; McPhie, J. 2002. The Eucarro Rhyolite, Gawler Range Volcanics, South Australia: AN 675 km3 compositionally zoned felsic lava of Mesoproterozoic age. Geological Society of American Bulletin 114: 1592-1609.

Allen, S.R.; McPhie, J.; Ferris, G.; Simpson, C. 2008. Evolution and architecture of a large felsic Igneous Province in western Laurentia: The 1.6 Ga Gawler Range Volcanics, South Australia. Journal of Volcanology and Geothermal Research 172 (1-2): 132-147.

Boynton, W.V. 1984. Geochemistry of the rare earth elements: meteorite studies. In Rare Earth Element Geochemistry (Henderson, P.; editor). Elsevier: 63114. Amsterdam.

Cingolani, C.; Varela, R.; Dalla Salda, L.; Kawashita, K. 1993. Los granitoides del Cerro Veladero, río de la Troya, provincial de La Rioja: estudio geocronológico e implicancias tectónicas. In Congreso Geológico Argentino, No. 12 y Congreso de Exploración de Hidrocarburos, No. 2, Actas 4: 68-74. Buenos Aires.

Cisterna, C.E.; Coira, B.; Koukharsky, M. 2006. Deformación dúctil en el Valle de Pastos Largos, extremo noroccidental del Sistema de Famatina. Revista de la Asociación Geológica Argentina 6: 149-154.

Cisterna, C.E.; Coira, B.; Koukharsky, M. 2010. Sucesiones volcánicas-sedimentarias tremadocianas y arenigianas en la sierra de Las Planchadas-Narváez: registros evolutivos del arco magmático famatiniano. Revista de la Asociación Geológica Argentina 66 (1): 178-191.

Cisterna, C.E.; Coira, B.; Koukharsky, M.; Zappettini, E.; Santos, J.O. 2013. Volcanismo carbonífero posorogénico en el río de Las Lozas, valle de Chaschuil, Catamarca, Argentina: nuevas evidencias de extensión en el borde occidental de Gondwana. In Simposio Argentino del Paleozoico Superior, No. 6, Actas 1: p. 8. Buenos Aires.

Coira, B.; Cisterna, C.E.; Koukharsky, M. 2005. Sucesión hialoclástica-lávica, bimodal, ordovícica de la quebrada de las Lozas, Puna Catarmarqueña, Argentina. In Congreso Geológico Argentino, No. 16, Actas 4: 679-686. La Plata.

Cuerda, A.J. 1965. Estratigrafía de los depósitos neopaleozoicos de la sierra de Maz (provincia de $\mathrm{La}$ Rioja). In Jornadas Geológicas Argentinas, No. 2, Actas 3: 79-94. Salta.

Dahlquist, J.A.; Galindo, C. 2004. Geoquímica isotópica de los granitoides de la sierra de Chepes: un modelo geotectónico y termal, implicanciaspara el orógeno famatiniano. Revista de la asociación Geológica Argentina 59: 57-69. 
Dahlquist, J.A.; Pankhurst, R.J.; Rapela, C.W.; Casquet, C.; Fanning, C.M.; Alasino, P.; Báez, M. 2006. The San Blas Pluton: An example of Carboniferous plutonism in the Sierras Pampeanas, Argentina. Journal of South American Earth Sciences 20: 341-350.

Dahlquist, J.A.; Pankhurst, R.J.; Rapela, W.C.; Galindo, C.; Alasino, P.; Fanning, C.M.; Saavedra, J.; Baldo, E. 2008. New SHRIMP U-Pb data from the Famatina Complex: constraining Early-Mid Ordovician Famatinian magmatism in teh Sierras Pampeanas, Argentina. Geológica Acta 6: 319-333.

Dahlquist, J.A.; Alasino, P.; Eby, G.N.; Galindo, C.; Casquet, C. 2010. Fault controlled Carboniferous A-type magmatismin the proto-Andean foreland (Sierras Pampeanas, Argentina): geochemical constrains and petrogenesis. Lithos 115: 65-81.

Dahlquist, J.A.; Pankhurst, R.J.; Gaschnig, R.M., Rapela, C.W.; Casquet, C.; Alasino, P.; Galindo, C.; Baldo, E.C. 2013. Hf and $\mathrm{Nd}$ isotopes in Early Ordovician to Early Carboniferous granites as monitord of cristal growth in the Proto-Andean margin of Gondwana. Gondwana Research 23: 1617-1630.

De Paolo, D.J. 1981. Trace element and isotopic effects of combined wall-rock assimilation and fractional crystallisation. Earth Planettary Science Letters 53: 189-202.

Gorton, M.P.; Schandl, E.S. 2000. From continents to island arcs: a geochemical index of tectonic setting for arcrelated and within-plate felsic to intermediate volcanic rocks. The Canadian Mineralogist 38: 1065-1073.

Grissom, G.C.; De Bari, S.M.; Lawrence, W.S. 1998. Geology of the Sierra de Fiambalá, northwestern Argentina: implications for Early Palaezoic Andean tectonics. Geological Society of London, Special Publication 142: 297-323.

Grosse, P.; Söllner, F.; Báez, M.; Toselli, A.; Rossi, J.; De La Rosa, J.D. 2009. Lower Carboniferous post-orogenic granites in central-eastern Sierra de Velasco, Sierras Pampeanas, Argentina: U-Pb monazite geochronology, geochemistry and Sr-Nd isotopes. Journal of Earth Sciences 98 (5): 1001-1025.

Höckenreiner, M.; Söllner, F.; Miller, H. 2003. Dating the TIPA shear zone: an early Devonian terrane boundary between the famatinian and Pampean systems (NW Argentina). Journal of South America Earth Sciences 16: 45-66.

Irvine, T.N.; Baragar, W.R.A. 1971. A Guide to the Chemical Classification of the Common Volcanic Rocks. Canadian Journal of Earth Sciences 8 (5): 523-548.

Le Bas, M.J.; Le Maitre, R.W.; Streckeisen, A.; Zanettin, B. 1986. A chemical classification of volcanic rocks based on the total alkali-silica diagram. Journal of Petrology 27 (3): 745-750.

Lofgren, G. 1971. Experimentally produced devitrification textures in natural rhyolite glass. Geological Society of America Bulletin 82: 553-560.

López de Lucchi, M.G.; Rapalini, A.E.; Siesgesmund, S.; Steeken, A. 2004.Application of magnetic fabrics to the emplacement and tectonic history of Devonian granitoids in central Argentina. In Magnetic fabric: Methods and Applications (Martín-Hernández, F.; Lüneburg, F.; Aubourg, C.; Jackson, M.; editors). Geological Society of London, Special Publications, 238: 447-474.

Llambías, E.J.; Sato, A.M.; Ortiz Suárez, A.; Prozzi, C. 1998. The granitoids of the Sierra de San Luis. In The Proto-Andean margin of Gondwana (Pankhurst, R.J.; Rapela, C.W.; editors). Geological Society of London, Special Publications 142: 325-341.

Martina, F.; Viramonte, J.M.; Astini, R.A.; Pimentel, M.M.; Dantas, E. 2011. Mississippian volcanism in the south-central Andes: New U-Pb SHRIMP zircón geochronology and whole-rock geochemistry. Gondwana Research 19 (2): 524-534.

McPhie, J.; Doyle, M.; Allen, R. 1993. Volcanic Textures: a guide to the interpretation of textures in volcanic rocks. Centre for Ore Deposits and Exploration Studies, University of Tasmania, Hobart: 198 p. Tasmania.

Meschede, M. 1986. A method for discriminating between different type of mid-ocean ridge basalts and continental tholeiites with the Nb-Zr-Y diagram. Chemical Geology 56: 207-218.

Mori, P.E.; Reeves, S.; Correia, C.T.; Haukka, M. 1999. Development of a fused glass-disc XRF facility and comparison with the pressed powder pellet technique at Instituto de Geociências, São Paulo University. Revista Brasileira de Geociências 29 (3): 441-446.

Mpodozis, C.; Kay, S.M.; Gardeweg, M.; Coira, B. 1997. Geología de la región de Valle Ancho-Laguna Verde (Catamarca, Argentina): una ventana al basamento del extremo sur de la zona volcánica de los Andes Centrales. In Congreso Geológico Chileno, No. 7, Actas 3: 1689-1693. Antofagasta.

Murphy, M.T.; Marsh, B.D. 1993. Textures and magmatic evolution of intermediate-composition dome complexes: evidence from the northern Tatoosh complex, southern Washington Cascades. Journal of Volcanology and Geothermal Research 54: 197-220.

Navarro, M.S.; Andrade, S.; Ulbrich, H.H.; Gomes, C.B.; Girardi, V.A.V. 2008. The direct determination of rare 
earth elements in basaltic and related rocks using ICPMS: testing the efficiency of microwave oven sample decomposition procedures. Journal of Geostandards and Geoanalytical Research 32: 167-180.

Pankhurst, R.J.; Rapela, C.W.; Saavedra, J.; Baldo, E. Dahlquist, J.; Pascua, I.; Fanning, C.M. 1998. The Famatinian magmatic arc in the central Sierras Pampeanas: An Early to Mid-Ordovician continental arc on the Gondwana margin. In The Proto-Andean margin of Gondwana (Pankhurst, R.J.; Rapela, C.W.; editors). Jounal of the Geological Society of London, Special Publications 142: 343-67.

Pearce, J.A. 1983. Role of sub-continental lithosphere in magma genesis at active continental margins. In Continental Basalts and Mantle Xenoliths (Hawkesworth, C.J.; Nurry, M.J.; editors). Shiva Publishing: 230-249. London.

Pearce, J. 1996. Sources and settings of granitic rocks. Episodes 19: 120-125.

Pearce, J.A.; Harris, N.B.W.; Tindle, A.G. 1984. Trace Element Discrimination Diagrams for the Tectonic Interpretation of Granitic Rocks. Journal of Petrology 25 (4): 956-983.

Peccerillo, R.; Taylor, S.R. 1976. Geochemistry of Eocene calc-alkaline volcanic rocks from the Kastamonuárea, northern Turkey. Contributions to Mineralogy and Petrology 58: 63-81.

Rubiolo, D.; Seggiaro, R.; Hongn, F. 2001. Mapa de la Hoja Geológica 2769-IV Fiambalá, provincias de Catamarca y La Rioja. Programa Nacional de Cartas Geológicas 1:250.000, SEGEMAR, Boletín 361: 90 p. Buenos Aires.

Sato, K.; Tassinari, C.C.G.; Kawashita, K.; Petronilho, L. 1995. O método geocronológico Sm-Nd no IGC-USP e suas aplicações. Anais da Academia Brasileira de Ciências 67: 313-336.

Seggiaro, R.; Hongn, F.; Folguera, A.; Clavero, J. 2000. Hoja Geológica 2769-II. Paso de San Francisco. Programa Nacional de Cartas Geológicas 1:250.000, SEGEMAR, Boletín 294: 52 p. Buenos Aires.

Self, S.; Thordarson, T.; Keszthelyi, L.; Walker, G.P.L.; Hon, K.; Murphy, M.T.; Long, P.; Finnemore, S. 1996. A new model for the emplacement of Columbia River Basalts as large, inflated pahoehoe lava flow fields. Geophysical Research Letters 23: 2689-2692.

Siesgesmund, S.; Steeken, A.; López de Lucchi, M.G.; Wemmer, K.; Hoffmann, A.; Mosch, S. 2004. The Las Chacras- Potrerillos batholith (Pampean Ranges, Argentina): structural evidence emplacement and timing of the intrusion. International Journal of Earth Sciences 93: 23-43.
Sims, J.P.; Irteland, T.R.; Camacho, A.; Lyons, P.; Pieters, P.E.; Skirrow, R.G.; Stuart-Smith, P.G.; Miró, R. 1998. $\mathrm{U}-\mathrm{Pb}, \mathrm{Th}-\mathrm{Pb}$ and $\mathrm{Ar} / \mathrm{Ar}$ geochronology from the southern Sierras Pampeanas, Argentina: implications for the Pelozoic tectonics evolution of the western Gondwana margin. In The Proto-Andean margin of Gondwana (Pankhurst, R.J.; Rapela, C.W.; editors). Geological Society of London, Special Publications 142: 259-281.

Shellnutt, J.G.; Jahn, B.M. 2011. Origin of Late Permian Emeishan basaltic rocks from the Panxi region (SW China): Implications for the Ti-classification and spatial-compositional distribution of the Emeishanflood basalts. Journal of Volcanology and Geothermal Research 199: 85-95.

Talusani, V.R. 2010.Bimodal tholeiitic and mildly alkalic basalts from Bhir area, central Deccan Volcanic Province, India: Geochemistry and petrogenesis. Journal of Volcanology and Geothermal Research 189: 278-290.

Tassinari, C.C.G.; Medina, J.; Pinto, M.S. 1996. Rb-Sr and Sm-Nd geochronology and isotope geochemistry of central Iberian metasedimentary rocks (Portugal). Geologie en Mijnbouw 75: 69-79.

Turner, J.M. 1960. Estratigrafía del tramo medio de la Sierra de Famatina y adyacencias (La Rioja). Academia Nacional de Ciencias 42: 77-126.

Turner, J.M. 1967. Hoja Geológica 13b, Chaschuil (Prov. de Catamarca y la Rioja). Instituto Nacional de Geología y Minería, Boletín 106: 125 p. Buenos Aires.

Varela, R.; Basei, M.A.S.; Sato, A.M.; Passarelli, C.R.; Cavarozzi, C.E.; González, P.D. 2004. Nuevos datos isotópicos en la Sierra de Umango, antepaís andino a los $29^{\circ}$ : edad del granite de Guandacolinos. Boletim de Resumos 40 Anos de Geocronología no Brasil, Universidade de Sao Paulo, Instituto de Geociencias 1: 84 p.

Winchester, J.A.; Floyd, P.A. 1977. Geochemical discrimination of different magma series and their differentiation products using immobile elements. Chemical Geology 20: 325-343.

Wood, D.A. 1980. The application of a Th-Hf-Ta diagram to problems of tectonomagmatic classification and to establishing the nature of crustal contamination of basaltic lavas of the British Tertiary volcanic province. Earth and Planetary Science Letters 50: 11-30.

Zappettini, E.; Coira, B.; Santos, J.; Cisterna, C.E.; Belousova, E. 2015. Combined $\mathrm{U}-\mathrm{Pb}$ and $\mathrm{Lu}-\mathrm{Hf}$ isotopes from the Las Lozas volcanics, Chaschuil Valley, NW Argentina: evidence of lower Pennsylvanian extensional volcanism in western Gondwana. Journal of South American Earth Sciences 59: 13-18. 